\title{
AGENDAS DE POLIITICA SOCIAL Y CONSTRUCCIÓN DEMOCRÁTICA EN LA TRANSICIÓN CHILENA
}

\author{
Gonzalo Delamaza \\ Universidad de Los Lagos, Chile \\ gonzalo.delamaza@ulagos.cl
}

\section{RESUMEN}

Las políticas sociales han sido el campo de mayor innovación en la acción del Estado en Chile desde 1990. Estas políticas fueron concebidas como un factor clave para asegurar la gobernabilidad de la transición política, fortalecer el modelo económico y restablecer un vínculo entre el Estado y la sociedad. Este artículo examina algunas iniciativas políticas gubernamentales en distintas áreas de política social. Interesa saber de qué manera estas políticas y programas sociales han modelado la relación entre el nuevo Estado surgido de la negociación de fines de los ochenta con la sociedad chilena. Para ello, se revisan los enfoques generales que subyacen a esta política, para luego diferenciar orientaciones en su interior. Se distinguen cinco modalidades o tendencias en la política social chilena según sus orientaciones, gestión institucional y modalidad de vínculos con las organizaciones sociales. Dos de ellas surgieron como resultado de la aplicación de enfoques innovadores durante los noventa, que llevaron también a la creación de nuevas agencias. Una tercera se relaciona con la reorientación de políticas en las áreas tradicionales. Las dos últimas tendencias que se analizan se refieren a las interfaces entre la política social y la sociedad civil en el espacio local (organismos descentralizados y externalización -o tercerización- del vínculo).

Palabras clave: Políticas públicas, Sociedad civil, Transición a la democracia, Chile. 


\title{
SOCIAL POLICY AGENDAS AND CONSTRUCTION OF DEMOCRACY IN THE CHILEAN TRANSITION PROCESS
}

\begin{abstract}
Socifal policies have been the greatest field of innovation in Chilean state action since 1990. These policies were conceived as a key factor to ensure governance in the political transition to democracy, to strengthen the economic model and to re-establish a link between State and society. This article examines some governmental political initiatives in different areas of social policy. It is important to know how these social programs and policies have shaped the relationship between the new State, which emerged from the negotiations in the late 1980s, and the Chilean society. For this purpose, the general approaches which underlie this policy are reviewed, and then the orientations within them are differentiated. There are five different patterns or tendencies in Chilean social policy, according to their orientation, institutional management and type of relationship with the social organizations. Two of them arose as a result of the implementation of innovative approaches during the 1990s, which also led to the creation of new agencies. A third one is related with the reorientation of policies in traditional areas. The last two of the analyzed trends refer to the interfaces between the social policy and civil society at the local sphere (decentralized entities and externalization - or outsourcing - of the relationship)
\end{abstract}

Keywords: Public policies, Civil society, Transition to democracy, Chile. 


\section{INTRODUCCIÓN}

El rasgo distintivo y original de la transición chilena a la democracia, iniciada en I990, lo constituyó el hecho de que se realizó dentro de los marcos establecidos previamente por la dictadura militar (I973-I990). Ello permitió a las fuerzas que apoyaban a esta última conservar una gran influencia y poder, tanto en la esfera económica como en la política y cultural. En este contexto, la transformación principal fue la restauración de los procesos institucionales democráticos -aunque con limitaciones-, el ingreso de una nueva elite política a la administración del Estado y la posterior dinamización de las políticas públicas, especialmente en el área social, que abordamos en este artículo. Por estas razones es que el nuevo sistema político - una democracia incompleta- pierde su capacidad de interpretación y canalización de las demandas de la sociedad civil, consolidándose la ruptura de la matriz sociopolítica prevaleciente en el período democrático anterior a 1973.

El proceso político se había radicalizado a partir de 1983 con un ciclo de tres años de protestas nacionales masivas. Sin embargo, la salida democrática no se produjo por medio de una ruptura institucional, ni se tradujo en una reforma económica de significación. Al contrario, la estrategia política se basó en derrotar a Pinochet en un plebiscito que él mismo convocó y negociar posteriormente con sus representantes. Como el ordenamiento constitucional incluía resguardos institucionales para el orden establecido durante el régimen militar, las propuestas de cambio fueron restringidas. La estrategia económica continuó basándose en la apertura al exterior con hegemonía del gran capital, que desde 1985 venía produciendo resultados de crecimiento económico (Foxley 1995).

La expectativa de un sector importante de la oposición de la época, en orden a producir una amplia participación popular no se cumplió después de I990. El protagonismo se limitó a las elites políticas y económicas que negociaron los términos de la transición con la participación de las fuerzas armadas. Se desactivó el movimiento social opositor y no se reemplazó con formas participativas de nuevo tipo. La situación inédita planteada por el plebiscito de I988, donde la oposición derrotó a Pinochet dentro de los marcos de la transición diseñada por él mismo, impidió su continuidad a cargo del gobierno, pero no la de su marco constitucional y legal. Tampoco el resultado adverso aceleró los plazos de la transición, por lo que el gobierno saliente dispuso de un año y medio para aprobar diversas leyes, diseñar el espacio político electoral, consolidar la privatización de empresas, etc. (Otano 1995, Boeninger 1997).

Durante la transición chilena se dio la paradoja de que la sociedad civil, 
que había mostrado grados relativamente altos de movilización durante la segunda mitad del período militar, sufrió una importante desactivación, dando paso a lo que se ha denominado el desencanto y desafección de la política democrática. También se ha observado una progresiva despolitización de esta sociedad civil, tradicionalmente asociada a los actores políticos (Posner 2003, Silva 2004, Tedesco 2004). La fuerza relativa de la sociedad civil durante el régimen militar puede haber sido sobrevalorada en cuanto a su autonomía o su grado interno de articulación, pero el hecho es que cambió sustancialmente al modificarse el escenario político.

El fin de la dictadura planteó simultáneamente la recuperación de la democracia institucional y la necesidad de reconstruir los lazos entre el Estado y la sociedad sobre nuevas bases luego de la prolongada transformación sufrida. Diversos factores influyeron para que sólo se abordara parcialmente la primera tarea, posponiéndose la segunda. Entre ellos, la negociación política que sustituyó a la ruptura institucional y la transformación económica que a fines de los ochenta impulsaba el crecimiento económico. Como no hubo ruptura institucional, el marco legal posterior al régimen militar se inscribió dentro del orden constitucional de 1980 y fue limitado debido a la presión militar, que le otorgó al bloque político proclive al régimen militar, una suerte de poder de veto sobre la acción estatal (Moulian 1997). Este poder de veto se expresó durante los tres primeros gobiernos concertacionistas en el plano político-institucional -a través de los partidos de derecha- y también fuera de él, a través de lo que el dirigente de la derecha liberal Andrés Allamand llamó los poderes fácticos: la cúpula del gran empresariado, la Comandancia en Jefe del Ejército y el diario El Mercurio.

Sólo una vez finalizado el ciclo político de la Concertación, en 2oro, se comenzó a producir un nuevo ciclo de movilizaciones sociales, principalmente en oposición a grandes proyectos con consecuencias medioambientales negativas $y$, durante 20 I I, en pro de una profunda reforma del sistema educacional. La masividad, extensión y contenidos de las movilizaciones, reafirman el análisis que aquí se propone, en términos que los gobiernos de la Concertación desarrollaron nuevos vínculos con la sociedad civil, pero los subordinaron a los acuerdos políticos de gobernabilidad pactados al inicio de la transición. Ello limitó severamente el alcance de las reformas y no articuló una nueva forma de participación social democrática. Por ello el nuevo ciclo de movilizaciones ha realizado en oposición al gobierno de derecha, por fuera del sistema político y casi sin vínculos con éste. 


\section{LASPOLÍTICASPÚBLICASYLASOCIEDADCIVIL:INNOVACIÓN Y RESTRICCIONES EN EL MARCO DE LA TRANSICIÓN}

Las políticas sociales han sido el campo de mayor innovación en la acción del Estado desde 1990. Estas políticas fueron concebidas como un factor clave para asegurar la gobernabilidad de la transición política, fortalecer el modelo económico y restablecer un vínculo entre el Estado y la sociedad. La importancia del ámbito social de las políticas públicas excede su gran significación cuantitativa dentro del gasto público, que supera $70 \%$. Argumentaremos que su relevancia es tal que ha sustituido en parte el vínculo histórico de la sociedad chilena con el Estado, que se realizaba a través del sistema político y los partidos. Su impacto es de esta manera principalmente despolitizador.

Se examinan algunas iniciativas políticas gubernamentales en distintas áreas de política social. Interesa saber de qué manera estas políticas y programas sociales han modelado la relación entre el nuevo Estado surgido de la negociación de fines de los ochenta con la sociedad chilena. Para ello, se revisan los enfoque generales que subyacen a esta política, para luego diferenciar orientaciones en su interior. Estas diferenciaciones están basadas en el modo como se concibe y se estructura el vínculo con la sociedad, la noción de ciudadanía que se utiliza explícita o implícitamente y los instrumentos de participación implementados. Esto permite distinguir entre cinco orientaciones de política que, si bien comparten algunos rasgos, difieren sensiblemente en su vínculo social y en las consecuencias que producen sobre la sociedad.

Aquí se analizan las políticas sociales como despliegue de la estrategia política general de la transición democrática en su faceta más innovadora y de mayor impacto directo sobre los actores sociales. Se establecen variables analíticas para diferenciar orientaciones y agendas en su interior. Sin embargo, esas diferenciaciones operan en un marco común, relacionado con las condiciones generales del período post I990. También se examina en términos conceptuales el enfoque de ciudadanía y participación a partir del cual se quiere analizarlas.

\section{CONDICIONES Y DINÁMICA DE LAS POLÍTICAS SOCIALES}

En términos generales, el diseño de la transición buscaba evitar confrontaciones con el modelo económico precedente y se basó en un acuerdo político en el marco de la Constitución de I980. Consistente con ese diseńo, la política social fue un campo de iniciativa innovadora privilegiado. Los gobiernos democráticos traían una importante acumulación de estudios y trabajo de campo realizado por centros de estudio y organizaciones no gubernamentales (ONG), lo que les permitió 
contar con propuestas bastante desarrolladas acerca de cómo actuar una vez en el gobierno. Muchos profesionales que habían elaborado diagnósticos y propuestas asumieron cargos en ministerios e implementaron las nuevas agendas.

Existe una importante conexión entre las agendas de política social puestas en práctica en Chile y las vigentes en el campo internacional. La reinserción internacional de Chile fue una meta de política, pues era un campo en el cual el régimen militar había carecido casi por completo de logros. Ello se manifestó en diversas iniciativas de impacto social: la firma de compromisos y convenciones de las Naciones Unidas que obligan al Estado chileno, la creación de una Agencia de Cooperación Internacional (AGCI), el aporte de significativos recursos de la cooperación extranjera para nuevos programas gubernamentales y la reapertura e intensificación de relaciones con países con los cuales se habían deteriorado en el pasado (México y Cuba en América Latina y varios países de Europa Occidental).

A la vez, la dinámica internacional de grandes conferencias y cumbres mundiales fue especialmente activa durante la década del noventa y constituyó un escenario privilegiado para la participación de la recién recuperada democracia chilena y su énfasis en lo social. Es el período de la profundización del ajuste estructural -que en Chile ya había ocurrido-, el reinicio del crecimiento económico después de la "década perdida" de los ochenta, la recuperación de regímenes democráticos en prácticamente todos los países del continente y los procesos de paz en Centroamérica (Van Klaveren I998).

Aún bajo el régimen de Pinochet, en 1989 Chile había firmado la Convención de los Derechos de la Mujer (CEDAW). Junto con el retorno a la democracia en I990, Chile firmó la Convención de Derechos de la Infancia y emprendería una activa participación en foros internacionales dedicados a materias sociales. En I 995 se realizó, por iniciativa de Chile, la Cumbre Mundial de Desarrollo Social en Copenhague, que fue presidida por el embajador chileno Juan Somavía. Todo ello se reflejaba internamente en la prioridad en una política social activa, focalizada en grupos vulnerables o desaventajados, que buscaba corregir en parte los efectos de el modelo económico neoliberal y dotar de un nuevo rol al Estado (Molina I992, Raczynski y Serrano 2002). También en ese contexto nacional e internacional, la presencia de la sociedad civil, y en especial de las ONG de desarrollo, fue creciendo y haciéndose duradera (Scherer-Warren I999: 3 I y ss.).

La política social mirada como conjunto apuntaba a introducir elementos de equidad en un marco económico relativamente inalterado después del 
régimen militar y sobre el cual se tenía poca capacidad de incidencia. Se hacía cargo de aquello que estaba ocurriendo en el escenario internacional, sin embargo, las limitaciones y las áreas no cuestionadas del ordenamiento económico y político heredado de Pinochet limitaron esas reformas.

En los noventa, hubo avances principalmente en el aumento del gasto público y su priorización del área social, pero no se modificaron aspectos básicos de la institucionalidad heredada del régimen anterior. Chile ya venía participando de la internacionalización del policy making en materia social con las reformas del período militar, como en el caso de la creación de las Administradoras de Fondos de Pensiones (AFP) privadas y su posterior exportación a otros países. Lo continuó realizando durante los noventa con la creación de programas y políticas sociales. El prestigio general de la transición era motivo suficiente para la exportación de programas sociales, más allá de su éxito específico. Así ocurrió a comienzos de los noventa con el programa de capacitación laboral Chile Joven, de nulos resultados, y luego con el Sistema Chile Solidario, adoptado en otros lugares antes de mostrar siquiera resultados concretos en Chile.

Hubo diferencias internas en las formas de implementación de la política social: por la prioridad otorgada de cada uno de los gobiernos post I990, por el impacto de la agenda internacional, por la existencia o no de contrapartes sociales organizadas y por las características institucionales de cada sector, que indican cierta diferenciación interna del Estado chileno. Por ello se constituyen diferentes agendas que establecen distintos modos de vinculación con la sociedad civil, evolucionan de diferente manera y por lo tanto, ofrecen potencialidades democratizadoras también disímiles.

En este artículo se distinguen cinco modalidades o tendencias en la política social chilena según sus orientaciones, gestión institucional y modalidad de vínculos con las organizaciones sociales. Dos de ellas surgieron como resultado de la aplicación de enfoques innovadores durante los noventa, que llevaron también a la creación de nuevas agencias. Una tercera se relaciona con la reorientación de políticas en las áreas tradicionales. Aquí se distinguen dos etapas: hasta el año 2000 se trata de la incorporación de nuevos programas y de un significativo aumento de los recursos, pero sin una modificación de la arquitectura institucional y el marco normativo establecido durante los ochenta. A partir del gobierno de Ricardo Lagos (2000-2006), se inicia una profunda reforma de la salud, reflejando un cambio de enfoque y una modificación parcial de la institucionalidad del sector. Durante el gobierno de Michelle Bachelet (2006-20Io), los estudiantes secundarios fuerzan con su movilización el cambio de la Ley Orgánica Constitucional de Educación y, al mismo tiempo, se estudia un rediseño del sistema previsional y se promulga una 
reforma parcial del sistema. Es decir, se ingresa a una etapa de reformas a la institucionalidad social, que se analizará sólo en el caso de la salud, siendo la única reforma plenamente implementada al momento de redacción de este artículo ${ }^{\mathrm{I}}$. A partir de mayo de $20 \mathrm{II}$, se inician nuevas movilizaciones masivas y sostenidas de estudiantes universitarios y secundarios, así como de profesores en demanda de una profunda reforma educacional.

Las dos últimas tendencias que se analizan se refieren a las interfaces entre la política social y la sociedad civil en el espacio local. La primera analiza los organismos descentralizados y su rol. La segunda aborda dos estrategias de externalización -o tercerización- del vínculo, a través de instituciones específicas de carácter paraestatal que intentaron corregir las dificultades de la institucionalidad existente.

El análisis también se detendrá en el período posterior al año 2000, durante el cual se ha reintroducido el debate sobre las nociones de ciudadanía como agencia -principalmente individual-y participación en ámbitos acotados de la política. Con ello se ha puesto en tensión el diseño de gobernabilidad establecido anteriormente y débilmente contestado durante el primer decenio de la transición a la democracia. No se trata de un cambio radical ni con un sentido unívoco, pues las iniciativas implementadas obedecen a diferentes enfoques, no necesariamente articulados entre sí. Sin embargo, marcan un cambio respecto de los enfoques de superación de la pobreza que predominaron hasta esa fecha.

Este cambio se hace visible tanto en la reforma de la salud como en el Sistema Chile Solidario: ambos se refieren a garantías sociales explícitas, exigibles ante la justicia y por lo tanto propias del enfoque tradicional de ciudadanía garantizada por el Estado. Pero, en el segundo caso, se trata de una nueva combinación de derechos sociales garantizados y políticas focalizadas hacia la extrema pobreza. En ninguno de los dos casos se contempla un rol claro para la sociedad civil ni se considera la participación deliberativa y organizada, limitando la profundidad del cambio (Contesse y Delamaza 2005).

De manera simultánea, desde 2002 se impulsa una Ley de Asociatividad y Participación Ciudadana en la Gestión Pública, aprobada a mediados de 20Io, con la que se busca dotar al Estado de mecanismos de participación institucionalizada, aunque no incorporando formas de democracia directa. En cierto modo este proyecto de ley es tributario de las concepciones

I La reforma a la seguridad social o reforma previsional fue promulgada el i I de marzo de 2008, exactamente i 8 años después de iniciado el primer gobierno democrático. La Ley General de Educación, primer cuerpo legal de la reforma educacional, fue promulgada en marzo de 2009. En ambos casos resulta aún demasiado temprano para analizar su aplicación. 
promocionales de los años sesenta, pero adecuado al diseño general de la gobernabilidad actual. En vez de plantear un nuevo sistema de gobernanza y una modificación de los regímenes de ciudadanía, se centra en el fortalecimiento organizacional y en el acceso de las organizaciones a las estructuras del Estado a través de mecanismos de consulta (Delamaza 2005).

\section{ACTORÍa SOCIAL Y CIUDADANÍA EN LAS POLÍTICAS PÚbliCAS}

Una particularidad del enfoque de construcción democrática es que no se restringe al campo institucional. Antes bien vincula la dimensión institucional con los desarrollos que ocurren en el ámbito de los actores sociales, dada la estrecha imbricación entre actores situados en distintos niveles de poder y ámbitos de interés público. Desde el punto de vista de la actoría social, una concepción de este tipo, alojada progresivamente en prácticas al interior del Estado, daría una mejor base de sustentación a un régimen ampliado de ciudadanía. Dicho régimen no se limita a su dimensión pasiva (reconocimiento de derechos), sino que incluye la ciudadanía activa y deliberante (Jones y Gaventa 2002): una relación entre la sociedad civil y el Estado que instituye cursos y mecanismos de co-participación de quienes no ejercen directamente el poder político institucionalizado. Estos participan en la definición de intereses, prioridades y control del quehacer público, buscan incidir en la toma de decisiones, deliberan argumentativamente acerca de los temas de la agenda que preocupa a la comunidad política y coordinan sus esfuerzos de generación y ampliación de bienes públicos que ni el Estado ni el mercado aseguran por sí solos.

La incorporación de nuevas prácticas participativas en la acción estatal en Chile ha sido mucho más restringida, en el marco de una democracia de baja intensidad y creatividad institucional y fuertes desigualdades sociales. Han sido principalmente las estrategias y políticas focalizadas de desarrollo social o local, implantadas en los ochenta y reformadas en los noventa, las que instalaron prácticas y sistemas participativos a escala micro-social o territorial (Taylor 1996, Guerra 1997, Greaves 2003). Algunos de estos espacios han evolucionado hacia la creación de instancias directas de diálogo, concertación y deliberación pública entre segmentos del Estado y actores de la sociedad civil; es decir, no mediatizados por el sistema político ni incorporados formalmente a él.

Los estudios disponibles sobre asociatividad, instrumentos legales de participación local, experiencias innovadoras y percepción ciudadana muestran un conjunto de conclusiones bastante homogéneo que conviene sintetizar (PNUD 2000, SUBDERE 2004; Más Voces 2005, Delamaza y Ochsenius 2007, Foster 20I0). En primer término, existe una alta 
tasa de asociatividad en Chile, especialmente de primer grado, de mayor densidad en zonas rurales, aunque de escasa interlocución e incidencia en políticas y orientaciones de gestión pública. En segundo lugar, los escasos instrumentos participativos dispuestos por ley son poco conocidos y se utilizan de modo irregular y parcial en la gran mayoría de los municipios del país. Por su parte, las expectativas de la población sobre instancias de participación no se corresponden con la oferta existente.

A su vez, los estudios de caso sobre innovación en la gestión social local e instalación de mecanismos de participación asociados a la política pública permiten también caracterizar el panorama en relación con los instrumentos de participación utilizados (Montecinos 2005a, 2007, Ochsenius 2006, Espinoza 2004, Fernández y Ordóñez 2007). Los instrumentos existentes responden a variados modelos de participación y no muestran un patrón común. Desde el punto de vista de su sostenibilidad, en general poseen bajo nivel de institucionalización y perdurabilidad en el tiempo. La ciudadanía convocada está conformada principalmente por personas pertenecientes a asociaciones formales, estando ausentes las organizaciones informales y/o los ciudadanos individualmente considerados. Las formas utilizadas son mayoritariamente cara a cara con autoridades y agencias públicas, las cuales priman por sobre las formas mediatizadas. Así, por ejemplo, hay baja ocupación de tecnologías de la información y comunicación. La participación alcanza normalmente el nivel informativo y consultivo y escasamente el deliberativo y/o de control social. Por último, los esfuerzos se concentran mayoritariamente en la ejecución de servicios, programas y fondos de gestión, influyendo débilmente en otras fases decisivas del ciclo de la política pública, como la formación de la agenda pública y la definición de políticas, medidas o decisiones públicas.

Los resultados de las agendas participativas dependen, entonces, del modelo adoptado por cada una de ellas y, muy especialmente, del tipo de contrapartes sociales y territoriales con que se vincula en su aplicación. Es decir, existen diferentes maneras de relacionar a los actores de la sociedad civil con las agencias de política pública, estructurándose redes de política de muy distinto alcance, sustentabilidad e impacto.

Los diferentes sectores de la administración definen agendas particulares de participación ciudadana que se expresan en programas y acciones específicas. Ellas se explican por varios factores: su propia tradición institucional, la existencia o no de interlocutores y demanda social definida, la manera como se negoció con ellos durante un momento histórico o coyuntural particular -el inicio de la transición- y según la influencia en la agenda de actores internacionales de política. En el Estado chileno se han ido superponiendo agencias, diseños institucionales y orientaciones, que 
coexisten con diverso poder e importancia en la actualidad, al modo de capas geológicas del aparato estatal.

En la acción estatal se puede distinguir las agendas y agencias del antiguo Estado democrático, un Estado con mayor peso social y económico, anterior a la dictadura militar, más o menos transformadas por las reformas de los ochenta. Esas agendas sobreviven principalmente en la expectativa de las personas y la reivindicación de los actores sociales organizados. Ello pudo apreciarse en las movilizaciones estudiantiles de 20 i y el amplio apoyo que suscitaron en la población las demandas por mayor presencia estatal y fin al lucro en la educación. Por otra parte están las agendas, agencias y modalidades que nacieron de las reformas del período militar, como los establecimientos educacionales y de salud que fueron transferidos a los municipios en I98 I. También es posible distinguir las modalidades surgidas del diseño original de la transición, elaboradas en los centros de estudio y ONG durante los ochenta. Finalmente, están las acciones y programas a partir de la influencia de organismos y acuerdos internacionales en el contexto de la reinserción internacional del país en los noventa, así como la nueva generación de reformas sociales durante los primeros años del siglo XXI (gobiernos de Lagos y Bachelet).

\section{LAS AGENDAS DE POLÍTICA PÚBLICA EN RELACIÓN A LA SOCIEDAD CIVIL}

Identificar las distintas modalidades de acción pública en relación con la sociedad civil permite establecer una primera distinción entre agendas de política que difieren en sus características, diseño, estrategia de implementación y resultados. En primer lugar, están las políticas focalizadas que surgieron a comienzos de los noventa en respuesta a demandas explícitas de los movimientos sociales. Estas políticas fueron producto de la negociación política previa a I 990 con movimientos sociales que formaron parte de la movilización antidictatorial. Estos lograron incorporar sus demandas en la agenda de la política social, aunque con diversos resultados, según el proceso legislativo y de gestión política posterior y según su evolución como movimiento. Interesan en particular aquellos sectores nuevos que carecían de presencia anterior y cuyas demandas ingresaron al Estado por esta vía, dando lugar a nuevas agencias estatales. A diferencia de ellos, el movimiento sindical también negoció sus demandas con la nueva conducción del ejecutivo en el inicio de la transición. Sin embargo, no se trataba de un movimiento nuevo, de tal modo que su presencia fue siempre considerada dentro de la agenda política de la democratización, respondiendo en términos generales a los patrones tradicionales de negociación política, institucionalización y vínculo con los partidos. Tampoco dio origen a nuevas agencias públicas, canalizándose a través de las estructuras tradicionales del Estado (principalmente el Ministerio 
del Trabajo). Los dos casos que se analizarán estuvieron en el inicio de la transición: los del movimiento de mujeres y los pueblos indígenas.

En segundo lugar, están las políticas innovadoras focalizadas frente a grupos vulnerables atomizados. Estas agrupan a instituciones y programas creados en respuesta a lo que se llamó la deuda social, sin tener tras ellos movimientos sociales constituidos, siendo más bien la propia agenda la que los constituye. Esto sucedió con actores que no lograron proyectarse adecuadamente en el nuevo escenario. Es el caso del movimiento más masivo y visible durante los ańos ochenta, el de pobladores urbanos, que no logró establecerse como interlocutor organizado al momento de la transición política, dejando la iniciativa principalmente en manos del gobierno y sus agencias (Taylor 1996, Salman I998, Paley 2001). Este tipo de políticas focalizadas y definidas completamente desde el gobierno se dieron en el caso de la extrema pobreza, los pobladores sin casa, los discapacitados, los microempresarios y los cesantes. Todos ellos han sido objeto de políticas inscritas en el paradigma de la superación de la pobreza. $\mathrm{Su}$ articulación con el conjunto de la política fue baja hasta 2006 -fecha en que se intenta una nueva agenda de protección social- así como lo ha sido su impacto general sobre el fortalecimiento de la sociedad civil y la condición de ciudadanía ${ }^{2}$.

Una tercera vertiente de políticas apunta a la reconstrucción de la ciudadanía social pasiva por medio de reformas institucionales con enfoque de derechos, aplicadas a sectores de política social tradicional. A diferencia de lo que se venía haciendo hasta 1999, con el gobierno de Ricardo Lagos se plantea una reforma institucional del sector salud que implica una redefinición de los estándares del régimen de ciudadanía, a partir de institucionalizar un enfoque neo-universalista en la política social. El sistema de Garantías Explícitas en Salud (GES) -conocido inicialmente como Plan AUGE- significa una obligación para el Estado en cuanto a garantizar atención de acuerdo con determinados protocolos para un conjunto amplio y preestablecido de patologías. Está en las antípodas de la política focalizada, cuyos límites están dados por la disponibilidad de recursos: aquí se trata de una garantía legalmente establecida a la cual el Estado debe responder. En el caso de que no tenga capacidad de hacerlo debe financiar la atención en el sistema privado. La tramitación de la reforma no estuvo articulada con la participación y gestión de redes

2 La introducción del Sistema Chile Solidario para abordar la extrema pobreza en 2003 y su ampliación hacia el diseño de un Sistema de Protección Social desde 2006, cubriendo infancia y previsión social para los adultos mayores, supone cambios en esta agenda, principalmente por la introducción de criterios del neo-universalismo, aunque de manera combinada con las políticas de superación de la pobreza. Se trata de una "lógica incremental de la protección social" (Robles 2009: 6I). 
asistenciales desarrollados previamente por ese mismo sector.

A partir de 2006, se plantearon reformas institucionales de envergadura en la seguridad social (previsión), que dio origen a una reforma y en la educación, ésta última producto de la movilización de los estudiantes de educación media, pero que no logró superar la negociación parlamentaria. El caso de la previsión social mantiene similitudes con la reforma de salud en cuanto a su enfoque, con el Estado como garante de ciertos derechos básicos, pero su agenda fue elaborada por medio de un procedimiento más participativo o de concertación en el diagnóstico y soluciones. Ello no ocurrió a través de la deliberación ciudadana ampliada, sino a través de la formación de una Comisión Asesora Presidencial. Igual metodología se intentó en el caso de educación. Esta metodología significó en los hechos una negociación con la oposición en la etapa pre-legislativa que, en la práctica, terminó restringiendo significativamente los alcances de estas reformas en cuanto al rol del Estado, al tiempo que hacía viable y expedita la tramitación legislativa (Aguilera 2009, Ruiz 2010).

En cuarto lugar, existe una modalidad de vínculo entre el Estado y la sociedad civil a través de agencias descentralizadas de política social, municipios y comunidades locales. Si bien la institucionalidad política chilena es de carácter unitario y centralizado, en I98 I se traspasó a los municipios la atención de la salud primaria y la educación básica y media. Luego de estas transferencias a los municipios se les fueron agregando nuevas funciones a lo largo de los noventa. Estas funciones se combinan con la institucionalidad de nivel regional, regulada en 1992, que permitió elegir por un método indirecto, Consejos Regionales (CORE) a fines de I993. En el ámbito del diseño y la operación de políticas, la institucionalidad parcialmente descentralizada se combina con las modalidades de ejecución de las instituciones del gobierno central. Estas son centralizadas en su diseño, pero operan a través de las agencias locales, en muchos casos constituyendo nuevas oficinas y programas municipales, aunque sin conformar nuevas instituciones descentralizadas. Por ello su evolución y efectividad dependen en general de la capacidad de formular proyectos locales de desarrollo y crear redes asociativas extensas, con ramificaciones extra-locales y vínculos políticos y sectoriales directos, no sólo centrados en el acceso al financiamiento.

Una última modalidad la constituyen los intentos de externalizar el vínculo con la sociedad civil con el fin de corregir las rigideces del diseño institucional y construir una interfaz más flexible. No se trata de nueva institucionalidad estatal, sino exclusivamente de la asignación de fondos a instancias paraestatales o mixtas, con participación de la sociedad civil, para canalizar acciones de política pública que no tienen cabida 
en la institucionalidad tradicional. Ello significó el traspaso de recursos a entidades autónomas, pero sustentadas a través del financiamiento público por medio de fondos y programas. Es el caso de agencias como el Fondo de las Américas (dedicado a temas ambientales) y la Fundación para la Superación de la Pobreza, especialmente a través de su Programa Servicio País. Estos programas dan lugar a dinámicas de participación de mayor intensidad y diversidad de actores, -corrigiendo parcialmente las distorsiones del ámbito político- aunque muestran dificultades de institucionalización.

La importancia de todas las distinciones anteriores nace de la siguiente consideración: las agendas de participación ciudadana (orientaciones de política e institucionalidad) y las redes de política pública conformadas en torno a ellas (espacios, mecanismos y contenidos de vinculación entre Estado y actores sociales) se convierten en componentes relevantes de la reforma democrática del Estado cuando son capaces de articular el enfoque de ciudadanía con políticas y prácticas de participación de la sociedad civil. Como se ha visto, estos componentes han tendido a estar escindidos en la política pública chilena.

\section{INNOVACIONES EN LA AGENDA SOCIAL}

Junto a las áreas tradicionales de la política social, desde I990 se crearon nuevas instituciones especializadas en el área social que debían hacerse cargo de los programas innovadores que marcarían la diferencia con el gobierno militar. Estas instituciones estaban focalizadas en grupos de la población considerados vulnerables y frente a los cuales no se habían desarrollado programas y políticas, adquiriendo así un enfoque potencialmente multisectorial. Se las agrupó en un nuevo ministerio creado para tal efecto: el Ministerio de Planificación Nacional (MIDEPLAN), nacido de la antigua Oficina de Planificación Nacional (ODEPLAN).

ODEPLAN fue creada en 1967 por el gobierno de Eduardo Frei Montalva (I964-I970) como organismo dependiente de la Corporación de Fomento de la Producción (CORFO). ODEPLAN fue el organismo que introdujo la función de planificación en el aparato público. Sin embargo, durante el gobierno militar esa función se discontinuó y en los hechos lo que hizo durante los ochenta fue administrar la red de subsidios sociales vinculada directamente a la Secretaría de la Presidencia. MIDEPLAN conservó la referencia a la planificación en su denominación, pero heredó la función que tenía durante el gobierno militar. A pesar de su nombre, este ministerio no realiza funciones de planificación: tiene a su cargo la evaluación e inclusión de proyectos en el Sistema de Inversión Pública y, a partir de I990, alberga a las instituciones focalizadas en sectores vulnerables 
y de extrema pobreza.

En I998, el presidente Eduardo Frei Ruiz-Tagle (I994-2000) anunció el cierre de MIDEPLAN, por considerar que no estaba cumpliendo una función necesaria. Sin embargo, ello no ocurrió y desde 2003 se hizo cargo del Sistema Chile Solidario y desde 2006 del Sistema de Protección Social. En el gobierno de Sebastián Piñera, iniciado en 20 io, se planteó una nueva modificación institucional a partir de MIDEPLAN: la conformación de un Ministerio de Desarrollo Social, que nuevamente intentará reunir a las diferentes agencias encargadas del tema.

En una primera etapa (I990-I99I), al alero del MIDEPLAN se constituyeron diversas instituciones especializadas en sectores sociales específicos considerados vulnerables: el Instituto de la Juventud (INJUV), el Servicio Nacional de la Mujer (SERNAM), la Comisión Especial de Pueblos Indígenas (CEPI, luego Corporación Nacional de Desarrollo Indígena, CONADI) y el Fondo de Solidaridad e Inversión Social (FOSIS). A mediados de los noventa se crearon el Servicio del Adulto Mayor (SENAMA) y el Fondo de la Discapacidad (FONADIS). También se adscribió a MIDEPLAN la AGCI, que luego fue transferida a la Cancillería. Más adelante se agregarían servicios especializados en áreas nuevas de intervención pública, como la Comisión Nacional de Medio Ambiente (CONAMA) y el Consejo Nacional para el Control del Consumo de Estupefacientes (CONACE). Ambas entidades se adscribieron al Ministerio Secretaría General de la Presidencia, marcando una diferencia de orientación del gobierno del presidente Frei Ruiz-Tagle respecto del precedente de Aylwin (I990-I994).

El impacto general de las instituciones innovadoras ha sido relativamente bajo en cuanto a alterar la situación de los grupos a los que están dirigidos, pues no han podido articularse eficazmente entre sí, a pesar de que varias pertenecen al mismo ministerio. Tampoco se han coordinado bien con la política social tradicional, que sigue teniendo un enfoque sectorial por falta de una autoridad social de nivel ministerial y por carecer de un lugar institucional definido dentro del sector público.

Sin embargo, estos organismos innovadores son los que introdujeron en la administración pública la preocupación por actores no considerados hasta ese momento, de tal modo que inciden en su visibilización, amplían la agenda gubernamental y establecen relaciones directas con los sectores sociales involucrados. La importancia de estas instituciones en el vínculo con la sociedad civil es muy grande, lo que contrasta con su menor impacto en cuanto a reorientar políticas. En algunos casos actúan bajo el amparo de leyes más o menos completas que deben ponerse en práctica, como el caso 
de la Ley Indígena, la Ley de Violencia Intrafamiliar y la Ley del Defensa del Consumidor (aprobada en 2004). Las primeras dos son ejemplos de instituciones que respondieron a demandas sociales estructuradas que se negociaron al comienzo de la transición. La necesidad de dictar cuerpos legislativos específicos ha implicado negociaciones y transacciones entre gobierno y oposición, lo que ha mermado en gran medida el alcance de las leyes que en un comienzo se impulsaron, como se verá en el caso de la Ley Indígena.

Las nuevas instituciones de política social nacidas en los noventa son las que mantienen contactos más permanentes con las organizaciones civiles del sector y han constituido un sinnúmero de instancias de participación en distintos niveles de implementación de la política. Sin embargo, el formato de proyectos de corta duración asignados competitivamente reduce la participación a una dimensión meramente instrumental la obtención del proyecto-, y no permite la construcción de formas asociativas más permanentes. Las metas, tiempos, modalidades y productos esperados de las instancias participativas tienden a volverse tecnocráticos o, en algunos casos, clientelares, en la medida en que se subordinan a la agenda de la institución, la cual no ha sido definida participativamente. La multiplicación de instituciones especializadas que convocan a la sociedad civil independientemente unas de otras produce una asociatividad fragmentada y efímera.

Lo importante de considerar en el análisis no es tanto la creación de instancias, sino su diseño específico y los modos de implementación, existiendo una diversidad de experiencias. De hecho, lo que se produce es una redefinición de la sociedad civil desde la política del Estado y no desde los propios actores. De una sociedad civil con connotaciones fuertemente políticas en los ochenta se pasó a una visión de pequeños grupos asociados para abordar problemas puntuales. La política, entonces, vuelve a remitirse exclusivamente al espacio estatal. Según Lucy Taylor, la nueva definición se basa en "finding local solutions for social problems perceived from an analysis of particularities of the local environment" (I996: 780). En la misma línea argumenta Edward Greaves (2003).

Todas estas instituciones han operado con el sistema de licitaciones y concursos de proyectos, destinados mayoritariamente a organizaciones no lucrativas de carácter local, profesionales o de membresía. Esto ha multiplicado los fondos públicos para el financiamiento de pequeños proyectos a través de múltiples ventanillas de financiamiento, logrando una significativa complementación de fondos de las organizaciones civiles a los programas de gobierno, pues casi siempre los proyectos suponen una importante cuota de co-financiamiento y/o trabajo voluntario por parte de 
la organización ejecutora.

Desde el punto de vista del financiamiento, estas instituciones estatales han contribuido a la subsistencia de organizaciones sociales de diverso tipo que han accedido en algún momento a la ejecución de los proyectos. Sin embargo, el sistema ha mostrado múltiples limitaciones para el desarrollo de una sociedad civil autónoma y con mayores capacidades: el bajo monto global comprometido y la excesiva fragmentación de los proyectos, los continuos cambios en las condiciones de los concursos, la corta duración de los proyectos, el carácter instrumental de la participación y la multiplicación de ventanillas. Esta situación es especialmente aguda para los programas focalizados en grupos considerados vulnerables y algo menos en aquellos que se estructuraron como respuesta a la demanda social de comienzos de los años noventa.

\section{POLÍTICAS FOCALIZADAS EN RESPUESTA A NUEVOS MOVIMIENTOS SOCIALES}

El primer conjunto reúne a políticas que surgieron de la negociación política previa a I990 con movimientos sociales que formaron parte de la movilización en contra del régimen militar. Dicha movilización estuvo fuertemente enraizada en la actividad de la sociedad civil organizada y, a partir de 1983, en la movilización masiva, más allá de las organizaciones. Los partidos políticos jugaron un rol importante, pero sin duda mucho menos gravitante que en el período previo al golpe militar, dadas las condiciones represivas. Fueron las redes sociales articuladas en torno a la Iglesia Católica, las ONG y los sindicatos reconstituidos a partir de I978, entre otras, las que sustentaron esa movilización. Destacan entre estos movimientos aquellos que representaron nuevos intereses y sensibilidades antes inexistentes en la política chilena y cuyo tratamiento posterior en la agenda pública también fue diferente de lo tradicional.

La suerte de esos movimientos fue dispar. El movimiento sindical, actor tradicional ligado a la política del centro y la izquierda, pasó a ser clave para el diseńo de la gobernabilidad de la transición y a ella subordinó su acción. El gobierno que se iniciaba, los empresarios y la central sindical establecieron acuerdos tripartitos explícitos, públicos y vinculantes con decisiones de política pública. De este modo los trabajadores organizados expresaron su apoyo también explícito al proceso de transición y contuvieron cualquier tipo de movilización que pudiese afectarlo. Es decir, el sindicalismo recobró su rol previo de actor social, reconocido como tal, aunque fuertemente debilitado por los cambios laborales y las restricciones de las leyes relativas a sindicalización y derecho huelga. A la vez, tal como ocurría regularmente en el período anterior a I973, subordinó su estrategia 
sindical a la estrategia política que le acarreaba beneficios en el Estado (Campero I998: 4I I, Delamaza I999: 387 y ss.).

Sin embargo, la novedad la portaban otros movimientos que no habían tenido participación política previa a la movilización de los ochenta. No estaban constituidos como actores políticos, ni tenían tampoco una historia de vinculación con los partidos políticos. La transición democrática ofreció una oportunidad de institucionalización de algunas de las demandas de estos grupos, dependiendo de factores que se analizarán. Lo importante, para efectos de clasificación, es que se trata de movimientos que adquirieron una capacidad negociadora en el contexto de la movilización política que condujo a la democratización. Interesa, por lo tanto, analizar las modalidades de relación que establecieron con las nuevas agendas de política.

Los resultados en cada uno de los casos son diferentes debido a las restricciones políticas en el parlamento, las modalidades de implementación, el rol de los diferentes actores (especialmente políticos y tecnócratas) y las formas de institucionalizar la participación de los grupos concernidos. Se analizarán los casos de las mujeres y del movimiento indígena, los principales ejemplos en los que nuevos actores sociales institucionalizaron formas de relación con el Estado en la nueva situación política abierta al finalizar el régimen militar, considerando la génesis, la institucionalización y la evolución posterior.

\section{MUJERES Y EQUIDAD DE GÉNERO: EL MOVIMIENTO DA LUGAR A LA POLÍTICA}

El movimiento de mujeres es quizás el que mayores logros ha obtenido en cuanto a institucionalizar su agenda en la política pública. En I990 se creó el SERNAM, que, aunque conserva hasta hoy el nombre de servicio, desde los inicios su Directora accedió al rango de Ministra, lo que no sucedió en ninguna de las demás situaciones que se revisarán. En cuanto a las políticas, se ha avanzado en la implementación de los acuerdos de la Convención por la Eliminación de toda forma de Discriminación contra la Mujer, se aprobaron la Ley contra la Violencia Intrafamiliar y un Plan Nacional de Igualdad de Oportunidades (1994), con sus respectivos planes regionales, y se lograron instancias de negociación de compromisos con otras reparticiones públicas. La creación del SERNAM fue el efecto directo de la acción de las organizaciones de mujeres en la movilización contra la dictadura (CEM 1993, Matear I995, Franceschet 2003).

Sin embargo, la institucionalización parcial de las demandas del movimiento feminista significó en la práctica un importante debilitamiento organizacional. Por otra parte, dicha agenda no tenía consenso dentro de la Concertación, lo que condujo a importantes divisiones y dificultó nuevos 
avances en la materia, situación que se prolongó hasta el gobierno de Michelle Bachelet (Baldez I 999, Ríos 2003, Valdés 2002). Con el tiempo, sin embargo, se consolidaron los avances y se introdujo la equidad de género en la corriente principal de la reforma administrativa a través de los Programas de Mejoramiento de la Gestión, que asocian cumplimento de metas con mejoras salariales de los funcionarios y que se aplican a todas las reparticiones públicas. Durante el gobierno de Bachelet estas orientaciones se intensificaron, dotando de continuidad y mayor profundidad a la política de equidad de género.

A pesar de los avances, el parlamento no ha aprobado la legislación contra la discriminación ni otras iniciativas relacionadas a la discriminación positiva y la ley de cuotas para los partidos políticos y el parlamento. Tampoco la Concertación alcanzó acuerdo interno en temas de derechos sexuales y reproductivos, por lo que no se registraron mayores avances en esa área. La distribución por parte del Ministerio de Salud de la píldora anticonceptiva, conocida como del día después, fue impedida por una resolución del Tribunal Constitucional a solicitud de parlamentarios de derecha.

La institucionalidad lograda ha experimentado algunos problemas con la asunción del gobierno de derecha de Sebastián Piñera, que se ha traducido en una fuerte reducción de su personal y en la posibilidad de que el SERNAM pierda su condición ministerial para pasar a depender del Ministerio de Desarrollo Social que se ha creado en 20 I I.

La agenda de equidad de género y la acción institucional del SERNAM han establecido modalidades específicas de relación con la sociedad civil que no se basan principalmente en el vínculo con organizaciones de base, sino que en lo que se ha denominado una "trama institucional de equidad de género" (Guzmán 2005). Esta trama establece un interfase múltiple y una institucionalidad cooperativa entre la institucionalidad pública (SERNAM) y los centros de estudio feministas con apoyo de la cooperación internacional y fuertes vínculos con el movimiento feminista en otros países (Varas 2006). Este vínculo permitió la movilidad de personal profesional y técnico entre la esfera estatal, los centros de estudio y los organismos internacionales ligados al tema durante los veinte años de gobierno de la Concertación.

La contracara de la institucionalización de la demanda femenina se encuentra, sin embargo, en el desperfilamiento del movimiento que la había construido. Una parte de la dirigencia se incorporó a las labores del nuevo organismo gubernamental, justamente aquella fracción que participó en la dirigencia política y que estaba inserta en las superestructuras de la 
Concertación a través del Comando de Mujeres por el NO y luego la Concertación de Mujeres por la Democracia a fines de los ochenta. Otro segmento profesional permaneció ligado a las ONG y centros de estudio, mientras el sector de las organizaciones de base se vinculó principalmente a los nuevos municipios y comenzó a colaborar en la gestión local. Sin embargo, mientras los centros de estudio son convocados por el SERNAM como consultores especializados para la formulación e implementación de políticas, tanto las ONG como las organizaciones de base sufren la pérdida del financiamiento internacional y carecen de espacio de interlocución con el gobierno.

A comienzos de 2003 se reinicia la discusión parlamentaria sobre la Ley de Divorcio, que para su aprobación debió ser negociada con la Iglesia Católica e incluir la validez civil del matrimonio católico. Un ejemplo de las dificultades para tramitar y elaborar políticas en este campo fue la formación de una bancada pro vida en el parlamento chileno. Esta bancada, políticamente transversal, nació para oponerse a la discusión de una iniciativa de despenalización del aborto que había sido presentada por parlamentarios de la Concertación. Los legisladores oficialistas de la bancada amenazaron con abandonar la coalición si se sometía a tramitación la iniciativa.

En general, las demandas de las mujeres han tendido a institucionalizarse parcialmente y sus activistas se han profesionalizado, no sólo por la legitimación selectiva de los programas gubernamentales, sino porque los temas de igualdad de género han penetrado en las agendas de los organismos internacionales, generando un activo proceso de construcción de redes internacionales de incidencia. El efecto interno de estos procesos es que, en palabras de la socióloga chilena Marcela Ríos "se han debilitado los lazos comunicantes y articulaciones entre los diversos componentes e individuos que circulan en el campo de acción feminista, y entre estos y otros actores de la sociedad civil" (2003: 322). Mientras el sector profesionalizado y con vínculos internacionales conserva una importante capacidad de incidencia en el debate y las propuestas de política -con los límites expuestos- el sector de organizaciones de base debe adaptarse a la oferta gubernamental sin poder influir en ella.

En otras palabras, en el caso de las mujeres se trata de una agenda fuerte en cuanto a la afirmación de la condición de ciudadanía, pues tiene soporte jurídico y una política de Estado que la respalda. Sin embargo, es débil respecto de la participación debido a la reducción y pérdida de relevancia relativa del movimiento social previo y la falta de estructuras institucionales. No obstante, a partir de la política pública y de la intervención de entidades civiles, se constituye un campo de disputa en torno a la equidad 
de género, en el cual participan actores políticos, organismos del Estado y organizaciones civiles, con articulaciones múltiples entre sí.

Instituciones como el SERNAM, y, en un grado mucho mayor, la CONADI, han sufrido permanentemente la tensión entre ser una agencia especializada del Estado dedicada a un sector determinado de la población y, al mismo tiempo, un espacio de representación o expresión de dicho sector al interior del Estado. En el caso del SERNAM la tensión existió, sobre todo en el primer período, cuando el movimiento de mujeres tenía mayor presencia. Sin embargo, el conflicto no se trasladó al plano institucional, ya que el SERNAM, a diferencia de la CONADI, no cuenta con mecanismo representativo alguno de sus beneficiarias principales. En general, las organizaciones de mujeres han encontrado espacios de alianza con la política de equidad de género frente a la oposición de derecha que ha intentado limitar sus alcances, como ocurrió frente a la distribución de la píldora del día después (Franceschet 2006).

También los grupos conservadores han intensificado su acción en el campo de la sociedad civil, principalmente a través de los llamados grupos pro vida y de la Iglesia Católica. El énfasis ha estado en las políticas de educación sexual, contracepción y planificación familiar, divorcio y aborto terapéutico. Su estrategia combina la influencia cultural y mediática con la vía judicial para restringir el alcance de la política gubernamental. Generalmente, centran sus críticas en el Ministerio de Salud (y secundariamente en Educación), sin enfrentarse directamente con el SERNAM y los programas innovadores.

\section{LA DEBILIDAD DE LA POLÍTICA DA PASO A UN NUEVO MOVIMIENTO INDÍGENA}

Otro caso es el movimiento indígena y la institucionalización progresiva de la demanda indígena en el Estado, inicialmente a través de la CEPI. Este organismo preparó y logró la aprobación de la Ley Indígena (I993) y dio origen a la Comisión Nacional de Desarrollo Indígena (CONADI) en 1996. Es un área de política fuerte en cuanto a participación institucionalizada, pero inorgánica al diseño de gobernabilidad imperante y a la implementación de las políticas que el acuerdo político admite. Al mismo tiempo, es débil en cuanto al enfoque de ciudadanía, pues no ha logrado el sustento legal que proponía el proyecto de Ley Indígena, sino algo mucho más reducido. Esta situación puede comenzar a cambiar con la aprobación del Convenio I69 de la Organización Internacional del Trabajo (OIT) en 2009.

En este período surgió un movimiento indígena de nuevo cuño, basado en reivindicaciones territoriales, alejado de los partidos políticos nacionales 
y con estrategias complejas de articulación entre el nivel local, nacional e internacional. Ello ha dado lugar a nuevas iniciativas gubernamentales, tanto programáticas como de diálogo político, con el activo concurso de la cooperación internacional, particularmente del Banco Interamericano de Desarrollo (BID) (Contesse y Delamaza 2005).

A comienzos de los noventa, nada hacía esperar que hacia finales de la década el conflicto mapuche tuviera tanta relevancia en la vida nacional. Durante el gobierno militar la propiedad comunitaria mapuche había sido convertida mayoritariamente en propiedad individual como parte de una política de asimilación. El nuevo gobierno democrático, aún antes de asumir, celebró un acuerdo formal en el llamado Parlamento de Nueva Imperial en 1989 con las autoridades de los diferentes pueblos indígenas, entre ellos con el principal grupo étnico del país, los mapuche, con el fin de acoger sus demandas y modificar las relaciones ancestralmente conflictivas entre el Estado chileno y los pueblos indígenas (Bengoa I999a). Este parlamento, a imagen y semejanza de los realizados durante la conquista entre españoles y mapuche, consistió en conversaciones y acuerdos que carecían de fuerza legal y no eran vinculantes, aunque sí contaban con peso político. Estos acuerdos derivaron en una negociación parlamentaria que redujo considerablemente sus alcances.

El movimiento mapuche contiene tres planos de reivindicación y búsqueda de reconocimiento que no son idénticos, no tienen el mismo peso, ni son uniformemente enarbolados por el conjunto de las organizaciones y comunidades. Cada uno de ellos ha sido enfrentado de diferente manera y con distintos resultados por las políticas gubernamentales. Esos niveles o tendencias son: la campesina, que privilegia los temas redistributivos y está ligada a la pobreza y a la falta de tierras y control de los recursos naturales; la étnica, que se traduce en demandas de ciudadanía multicultural y respeto y condiciones para reproducir su propia cultura, incluyendo el control de su territorio; y la etno-nacional, que emerge en los noventa y se refiere a las demandas por autonomía en tanto pueblo o nación (Foerster y Vergara 2000).

La relación entre el Estado y el movimiento mapuche ha estado marcada por la evolución de las respuestas gubernamentales a cada una de esas tendencias de búsqueda de reconocimiento, en un contexto en que el movimiento indígena adquiere un carácter más inclusivo de sus dimensiones o tendencias y reclama, por tanto, una resolución de carácter más integral.

Durante el primer gobierno democrático se constituyó la CEPI, que se ocupó de transformar los contenidos del Parlamento de Nueva Imperial en 
iniciativas legales e instrumentos de política. La Ley Indígena que se aprobó no representó, sin embargo, el proyecto político del primer gobierno de la transición, que incluía el reconocimiento constitucional de los pueblos indígenas, la ratificación del Convenio i 69 de la OIT y un proyecto de ley para el desarrollo indígena. Las dos primeras iniciativas fueron rechazadas por la derecha, mayoritaria en el Senado (volverían a ser rechazadas durante el segundo gobierno), y la ley fue reducida al derecho a la participación y a la tierra y el acceso y control de los recursos naturales (Bengoa I999a, Aylwin 2000). Los logros principales fueron la creación de la CONADI -con menor participación indígena de lo planteado inicialmente- y la constitución del Fondo de Tierras y Aguas Indígenas, creado para revertir el proceso de despojo de tierras que venía ocurriendo hace más de un siglo.

Entre los factores de conflicto a lo largo del período pueden citarse principalmente las restricciones de la ley indígena, las contradicciones de la política indígena y la evolución misma de la demanda mapuche en un contexto institucional no modificado cuyo punto crítico es el control sobre el territorio y los recursos naturales (Mallon 1999, Aylwin 2000, Toledo 200I). Por ello la demanda de las organizaciones mapuche en la segunda mitad de los noventa se refirió en primer término a la reclamación de tierras usurpadas o ancestrales para lo cual la política del Fondo de Tierras había sido insuficiente.

También se plantearon los conflictos a raíz la vertiginosa expansión de la industria forestal y posteriormente la minería y de proyectos de infraestructura (vial, hidroeléctrica, pública y privada). Un último punto de conflicto fue la falta de reconocimiento pleno, tanto en recursos como en ciudadanía, que forma parte de la plataforma internacional de los pueblos indígenas (Toledo 2005, 2006, Silva y Rodrigo 2010).

Mientras en América Latina esa reivindicación ha sido recogida de diversas formas por varios Estados (como en Nicaragua, Colombia, Bolivia, Panamá y México después del alzamiento maya/zapatista), en Chile continúa siendo considerada por grupos de elite como un grave riesgo para la unidad territorial y política del país. Sólo en septiembre de 2009 entró en vigencia el Convenio I69 sobre Pueblos Indígenas y Tribales en Países Independientes de la OIT, luego de I 6 años de tramitación legislativa y a un año de su ratificación. Chile es el décimo tercer país de América Latina en ratificar dicho Convenio.

El abogado chileno José Aylwin describe la evolución de las demandas indígenas de la siguiente manera:

De una demanda centrada en el derecho de los mapuche a la tierra y a la participación del aparato del Estado en la resolución de sus 
asuntos, se ha pasado a una demanda centrada en el reconocimiento de la territorialidad indígena hasta hoy negada en el país, así como del derecho a un desarrollo político y cultural autónomo al interior de dichos territorios (2000: II).

Pero no sólo el movimiento está reclamando autonomía territorial, sino que también está mostrando un importante grado de autonomía respecto de los partidos políticos. Esto marca una profunda diferencia con el pasado, cuando los partidos constituían un frente indígena y, correspondientemente, cada asociación indígena se adscribía o pactaba con alguno de esos partidos. Por otra parte, se detecta una tendencia creciente al surgimiento de identidades territoriales específicas al interior del mundo mapuche, consistente con la problemática que enfrentan actualmente. Surgen, por ejemplo, la Identidad Territorial Lafkenche, la Coordinadora Arauco-Malleco y otras vinculadas a los distintos grupos territoriales del pueblo mapuche, los pehuenche, los huilliche, etc. ${ }^{3}$. El conflicto ha incluido episodios de violencia provenientes de grupos mapuche que han recuperado tierras y también de las empresas forestales, otros propietarios agrícolas en conflicto y la policía (Lavanchy i 999, Toledo 2007, Centro de Derechos Humanos 2008).

La política gubernamental ha abordado el conflicto con distintas estrategias. En el plano policial, mientras el gobierno de Lagos utilizó la Ley Antiterrorista promulgada por Pinochet para perseguir a los grupos más radicales, el de Bachelet se comprometió a no aplicarla, luego de un informe del relator especial de Naciones Unidas para Pueblos Indígenas (Anaya 2009). El compromiso no se cumplió y se han producido diversos episodios de creciente uso de la fuerza policial en el manejo del conflicto y la demanda permanente de la derecha política y las agrupaciones empresariales por aplicar "mano dura" en los territorios mapuche (Toledo 2007).

En el campo social, a fines de los noventa se intentó un ambicioso programa de desarrollo que potenciara el débil desempeño del Fondo de Tierras. Sin embargo, este programa no surgió de los instrumentos regulares de la política indígena, ni se radicó en la CONADI, sino que se hizo posible a través de un préstamo del BID al gobierno chileno.

3 Se trata de diferencias de radicación geográfica asociadas a las actividades económicas: Huilliche $=$ gente del sur; pehuenche $=$ los que viven del pehuén (araucaria) que crece en las zonas cordilleranas de las regiones del Bío Bío y Araucanía; lafkenche = gente del mar, que vive de la pesca y la recolección de productos del mar en la zonas costeras de esas regiones. Cada unos de esos territorios han sido afectados de diferente manera por la expansión de la explotación forestal y la pesca industrial. Para un análisis de estos temas, ver Toledo (200I). 
La CONADI es el único de los organismos de política social innovadora que tiene un Consejo Directivo compuesto por representantes del Presidente de la República y por miembros elegidos directamente por las etnias reconocidas por la ley indígena. Este consejo ha atravesado diversos conflictos desde su creación, que no han surgido solamente de los consejeros indígenas, sino también de los nombrados por el Presidente cuando no han estado de acuerdo con la política oficial. Incluso ha ocurrido con los distintos directores mapuche de la CONADI, que han terminado enfrentados con el propio Presidente que los nomina. La institucionalidad de la CONADI ha sufrido crisis sucesivas, que se hicieron más agudas durante el gobierno de Eduardo Frei Ruiz-Tagle, a raíz del conflicto por la construcción de centrales hidroeléctricas en el Alto Bío Bío, que implicaba la migración de familias pehuenches (Namuncura 1999, Mallon 1999).

Frente a las sucesivas crisis de la institucionalidad indígena, el gobierno de Lagos recurrió al mismo mecanismo de diálogo político utilizado para otros conflictos y problemas: el nombramiento de una comisión de personalidades de carácter pluralista. En este caso fue la Comisión de Verdad Histórica y Nuevo Trato, presidida por el ex presidente Patricio Aylwin y compuesta por personas de diferentes posiciones políticas nombradas por el gobierno, junto a dirigentes del movimiento mapuche, también designadas por el gobierno. A mediados de 2003 la Comisión publicó su informe, aunque sus recomendaciones fueron escasamente difundidas, con excepción de la opinión minoritaria del consejero Felipe Morandé, economista de derecha y más tarde Ministro de Transportes de Piñera. El informe tampoco suscitó el apoyo de las organizaciones mapuche, a pesar de que sus dirigentes habían firmado el texto. Meses después, el propio gobierno tampoco se había pronunciado respecto de este informe que él mismo solicitó, perdiendo así su relevancia.

El gobierno de Bachelet impulsó la aprobación del Convenio i 69 de la OIT, siendo ratificado en el Parlamento en septiembre de 2009. También promovió un Acuerdo de Nueva Imperial II (2006), estableció una Agenda Indígena, constituyó una instancia interministerial de coordinación y, en 2008, nombró un Comisionado Presidencial para Asuntos Indígenas para proponer nuevas iniciativas que desactivaran el conflicto y permitiera la construcción de un Pacto Social por la Multiculturalidad (Centro de Derechos Humanos 2008 Programa Orígenes 2008). El Comisionado debió renunciar en agosto de 2009, quedando a cargo del tema el ministro Secretario General de la Presidencia. Todas estas iniciativas han rebasado la estructura de la CONADI, revelando su inadecuación institucional ${ }^{4}$.

$4 \mathrm{Al}$ asumir el gobierno Sebastián Piñera en 20ı, nombró un director de CONADI que debió ser removido a los pocos días por motivos de probidad. El gobierno enfrentó una prolongada huelga de hambre de 34 activistas mapuche presos que 
A pesar de las diferencias entre los dos casos-mujeres y pueblos indígenasen ellos se manifiestan la amplitud y orientación de las respuestas políticas a conflictos constituidos socialmente. Las herramientas de negociación utilizadas son fundamentalmente la adopción de algunos aspectos de sus demandas a través de legislación e instrumentos de política pública: nuevas instituciones, orientaciones de política más o menos amplias, programas y fondos. En ambos casos no se logra estructurar una adecuada relación con los movimientos sociales que dieron origen a la agenda política específica, ni se asegura plenamente el fortalecimiento de la ciudadanía, especialmente en el caso indígena.

En el caso de las mujeres, el logro institucional es mayor y la política más coherente. Pero trajo consigo la desactivación del movimiento y la fragmentación de la demanda y el fortalecimiento de una suerte de coalición de políticas de género, con mayor protagonismo de una elite político-técnica intra y extra Estado, que alcanzó incluso a la Presidenta Bachelet. En el caso indígena, en cambio, los instrumentos institucionales, legales y políticos han sido muy insuficientes, mientras el movimiento se reestructura de acuerdo con nuevas pautas de organización y orientación política no considerados en el sistema político de representación surgido de los acuerdos de I989.

Las agendas también difieren en sus ejes de conflicto. En el caso de las mujeres es la agenda de los derechos sexuales y reproductivos la que produce mayor disputa entre el movimiento feminista y la Iglesia Católica y los sectores conservadores. Es un conflicto que se proyecta al interior de la propia sociedad civil, donde las posiciones de la elites conservadoras limitan los avances y la contra elite feminista actúa dentro y fuera del gobierno.

En el caso indígena, específicamente en la situación del pueblo mapuche, el conflicto se intensifica -incluyendo un incremento de la represión policial- porque la disputa tiene una importante dimensión económica en relación a los recursos naturales y el territorio. Todo ello ocurre en un contexto de modernización compulsiva de la economía chilena, basada precisamente en la explotación de los recursos naturales y que carece de suficiente protección jurídica de los derechos ciudadanos y territoriales de las minorías étnicas. También debe considerarse la dimensión históricopolítica del conflicto, que evidentemente sobrepasa la capacidad de la política social para resolverlo. Por ello, en sucesivas ocasiones la iniciativa

demandaban el cese de la aplicación de la ley antiterrorista y mejores condiciones procesales y carcelarias. Nuevamente el encargado de negociar y de anunciar luego un Plan Araucanía y la creación de una Subsecretaría de Asuntos Indígenas fue el ministro Secretario General de la Presidencia. 
se desplaza de la institucionalidad establecida hacia otras formas de negociación política (Bengoa I 999a, Toledo 200I).

Por último, es relevante la presencia del factor internacional como soporte de la agenda pública por medio de convenios internacionales firmados por el Estado chileno y de programas de cooperación que han permitido sortear algunas de las limitaciones más fuertes de la institucionalidad e introducir innovaciones. Pero también el factor internacional ha estado presente como respaldo y soporte a las demandas de la sociedad civil, por cuanto los movimientos de mujeres y de pueblos indígenas cuentan con vínculos de cooperación con otros países, con grupos influyentes en países desarrollados, así como con estrategias de gestión frente a organismos internacionales. Ellos han presionado al Estado chileno para el cumplimiento de compromisos contraídos o han impuesto condicionalidades al desarrollo de ciertos proyectos. La estrategia internacional del gobierno chileno, que busca posicionar al país en el concierto de los países emergentes, está también en el origen de esta situación, otorgando mayor validez a los estándares internacionales hoy vigentes.

\section{POLÍTICAS FOCALIZADAS A GRUPOS VULNERABLES. DEL FOSIS AL SISTEMA CHILE SOLIDARIO}

La otra variante de la política social innovadora son las instituciones y programas creados como respuesta a lo que se llamó la deuda social (Raczynski et al. 1995). Son iniciativas gubernamentales que no tienen tras ellas movimientos sociales constituidos. Su grado de institucionalización es menor -de hecho varios son solamente fondos de financiamiento de proyectos- y por ello su articulación con el conjunto de la política es baja. Sus montos de financiamiento son muy inferiores a los de la política social tradicional, lo cual disminuye su impacto.

A diferencia de los casos anteriores, en éste es la política social la que constituye a los actores por la vía de reconocer la necesidad de pagar dicha deuda social e incorporarlos a una situación de mejores oportunidades. En relación a la política del gobierno militar, se mantuvo la focalización en los grupos pobres y vulnerables, pero se agregaron criterios de focalización, esta vez en grupos específicos o en la categoría de pobres y extremadamente pobres, que no aluden a un actor sino a un agregado heterogéneo.

El caso del FOSIS es interesante. Fue creado en I 990 como organismo dependiente del MIDEPLAN, responsable de ejecutar acciones contra la pobreza, apoyando los esfuerzos de la propia comunidad beneficiaria -los pobres urbanos y rurales-, en consonancia con las orientaciones de las ONG en los ochenta. En el tránsito de la movilización contra el régimen militar a la política social en democracia, la principal expresión organizativa 
del movimiento de pobladores no logró constituirse como interlocutor de las nuevas políticas como se postulaba en los ochenta. Sin embargo, la política social fue reactivada.

La política de vivienda permitió incrementar significativamente la cantidad de soluciones habitacionales, reduciendo el déficit habitacional que había aumentado durante el gobierno militar y modificando completamente el panorama de las ciudades y poblados, como del propio movimiento urbano (Rodríguez y Sugranyes 2005, Segovia y Daskal 2000, Aravena y Sandoval 2008). Por otra parte, se creó el FOSIS como una respuesta a los problemas de los más pobres, utilizando una estrategia de participación local y comunitaria (Taylor 1996). Mientras el movimiento social se desactivaba, la iniciativa gubernamental tomaba fuerza, con estrategias que fragmentaban aún más al movimiento.

ElFOSIS comenzócon el apoyo financiero dela cooperación internacional, que a partir de 1993 fue sustituido por partidas presupuestarias regulares. Recibió los aportes metodológicos de muchos profesionales provenientes del sector no gubernamental de los ochenta y amplió la oferta de recursos estatales. Ya no sólo se apoyaron programas definidos por el gobierno, sino también se acogieron iniciativas de las comunidades surgidas de procesos de planificación participativa. En general, los montos de financiamiento son muy reducidos y financian proyectos de corto plazo, utilizando mecanismos competitivos entre organizaciones sociales y ONG. Por ello no es posible sostener un trabajo permanente con el apoyo del FOSIS, sino sólo darle inicio o reforzarlo en un momento determinado de su desarrollo.

El FOSIS representó una innovación local respecto de los fondos de inversión social, instrumentos surgidos en el contexto de las políticas sociales paliativas del ajuste estructural en América Latina. Estos fondos se extendieron por todo el continente a comienzos de los noventa, pero el FOSIS subsistió a su declinación, entre otras razones porque fue el único donde el financiamiento externo no representó un porcentaje significativo de su presupuesto (Siri 2003: 2). Su vigencia dentro del Estado está dada principalmente por su especialización en los extremadamente pobres y en su modalidad de vinculación con la comunidad.

A pesar de su bajo impacto general, los programas y fondos focalizados tienen un rol relevante en cuanto a la estructuración de la asociatividad, especialmente a nivel de los sectores pobres, dado que allí está concentrada la actividad gubernamental. Estos programas constituyen en la práctica estructuras de incentivos para los grupos pobres y marcan su relación con el Estado en el último eslabón de la cadena de las políticas públicas. El Informe de Desarrollo Humano de 2000 señala la gran cantidad de 
asociaciones de diverso tipo en el país y caracterizan dicha asociatividad como fragmentada, sin vínculo con redes y con baja incidencia en el rumbo de las políticas públicas.

De hecho, los programas sociales hacia grupos prioritarios, así como otras agencias gubernamentales -como Chiledeportes y el Instituto de Desarrollo Agropecuario (INDAP)-inciden en las formas de asociación de los grupos pobres, pero lo hacen de un modo que no fortalece su permanencia en el tiempo y el desarrollo sostenido de sus capacidades. Si se considera que en términos presupuestarios éste es el sector que más ha crecido desde 1990 y que su relación con los grupos populares es directa, se comprende que a pesar de las limitaciones de diseño institucional, su contribución al desarrollo de la sociedad civil podría ser diferente.

De acuerdo a Lucy Taylor, la redefinición de la sociedad civil por parte de las políticas públicas a partir de 1990 utilizó "the twin strategies of incorporation and marginalization". Se refiere a la incorporación de grupos comunitarios locales y la marginalización de las dirigencias políticas de los pobladores. Las políticas puestas en práctica habrían sido la descentralización "and self-help projects set up through the auspices of FOSIS” (I 996: 780).

El Programa Nacional de Superación de la Pobreza coordinado por MIDEPLAN en I994-I995 fue el primer intento de articular el conjunto de las políticas contra la pobreza. Adoptó el enfoque territorial, seleccionando a 9I comunas prioritarias para organizar la inversión pública. Las metodologías de diagnóstico participativo y la constitución de una demanda comunal unificada (coordinada por las Gobernaciones provinciales) fueron el aporte de los programas innovadores. Sin embargo, el Programa fue rápidamente desactivado sin una evaluación de sus resultados. La falta de una autoridad social capaz de reorientar el contenido de la oferta pública hacia los territorios y la dificultad de obtener resultados a corto plazo le quitaron a este programa el respaldo político necesario, y fue descontinuado (Bengoa I999b; Raczynski y Serrano 2002).

Después de 2003 , la agenda de programas contra la pobreza se ha enfocado en un sistema de asignación de recursos denominado Chile Solidario, que comenzó a operar a través del Programa Puente del FOSIS (Palma y Urzúa 2005). Este sistema fue diseñado por el Ministerio de Hacienda con el fin de reducir los costos crecientes de una acción social que evaluaban como dispersa y descoordinada y el congelamiento de la cifra de personas en la extrema pobreza o indigencia.

Desde 1987 se han hecho públicos los resultados de la Encuesta de Caracterización Socioeconómica CASEN, y desde entonces el porcentaje 
de hogares y personas bajo la denominada línea de la pobreza ha disminuido en cada medición's Sin embargo, a partir de la encuesta de I 996, el porcentaje de familias ubicadas en la extrema pobreza se mantuvo estable e incluso tendió a crecer, a pesar de una disminución global de las familias pobres. Esto llevó a una evaluación crítica de las políticas contra la pobreza aplicadas hasta ese momento, realizada por la Dirección de Presupuesto del Ministerio de Hacienda, especialmente en lo referido a la red de beneficios asistenciales provistos por el sector público. El diagnóstico fue que existía una pobreza dura que no se beneficiaba de los efectos del crecimiento económico ni tampoco accedía a los servicios públicos, por desconocimiento, aislamiento, descoordinación y falta de cobertura de los mismos. Se planteó entonces la necesidad de articular mejor la red de beneficios asistenciales, asegurándolos para las familias extremadamente pobres, y se consideró la necesidad de otorgar un bono en dinero que suplementara los ingresos familiares, permitiéndoles así superar la línea de la indigencia (Ruz y Palma 2005).

Paralelamente, FOSIS readecuaba su enfoque de intervención con el fin de focalizar mejor su acción contra la pobreza. Su evaluación interna constataba dispersión territorial, bajos montos de inversión, muchos grupos con proyectos pequeños y demasiada diversidad de intervenciones (FOSIS 2002: 9). La readecuación consistió en la adaptación parcial del enfoque de Manejo Social del Riesgo desarrollado por el Banco Mundial (Holzman y Jorgensen 2000). Así se creó el Programa Puente, aplicado gradualmente a las 226.000 familias consideradas indigentes. Consistió principalmente en una estrategia de apoyo sicosocial a la mujer dueña de casa y la suscripción de un contrato entre la mujer (representando a la familia) y el o la profesional, normalmente también una mujer, denominada apoyo familiar, representando al Estado. Mediante este contrato el Estado se compromete a priorizar a dicha familia en el acceso a los subsidios y servicios que brinda y la familia a enviar a los niños al colegio, realizar los trámites necesarios, etc.

Los esfuerzos del Ministerio de Hacienda para asegurar a las familias un suplemento de ingreso y subsidios que les permitieran superar la indigencia, y los intentos del FOSIS por establecer algún sistema de protección contra el riesgo social convergieron y se convirtieron en prioridad por iniciativa del Presidente de la República. Se estructuró el Sistema de Protección

5 La línea de pobreza resulta de comparar el ingreso familiar con el valor promedio de una canasta familiar de alimentos, calculada de acuerdo al consumo de las familias según la Encuesta de Presupuestos Familiares de I986. Si el ingreso no supera el valor de dos canastas familiares promedio en el sector urbano, o I,75 en sector rural, se considera que la familia es pobre. Si no supera el valor de una canasta familiar promedio, se considera que es indigente o extremadamente pobre. Una revisión de la metodología de medición para 2007 en Larraín (2008). 
Social Chile Solidario con el Programa Puente como vía de ingreso de las familias al sistema. Chile Solidario no tiene como misión la superación de la pobreza, sino "incorporar a las familias de extrema pobreza a la red de protección social del Estado, de manera garantizada y/o preferencial (según sea el beneficio), lo cual supone la interacción, readecuación y vinculación efectiva de toda la oferta programática existente". Se estima que Chile Solidario "dará garantías mínimas para que las familias de extrema pobreza vivan con dignidad" (FOSIS 2002: 6). Los componentes del sistema son el apoyo sicosocial durante dieciocho meses, un Bono de Protección Familiar de monto decreciente a lo largo de cuatro semestres, Subsidios Monetarios Garantizados y el acceso preferencial a programas de promoción, prestaciones laborales y de previsión social (Arenas y Guzmán 2003, MIDEPLAN 2004).

Una innovación importante es que el Sistema Chile Solidario introduce la noción de derechos garantizados, pero no universales, como ocurre en la concepción socialdemócrata tradicional, sino focalizados en quienes han sido definidos previamente como beneficiarios. Con respecto a la sociedad civil, el enfoque de superación de la pobreza se reduce a la acción orientada a unidades familiares dispersas, sin consideración de las dimensiones territoriales ni comunitarias de la política social. El sistema no contempla el elemento de asociatividad y redes locales en ninguna de sus acciones, pues establece una red de atención directa (mediada por un contrato) entre el Estado y la familia en situación de pobreza, siempre que ésta haya sido previamente calificada como tal. Como es básicamente un mecanismo para racionalizar y focalizar al máximo el gasto social, tampoco consideró inicialmente un rol determinante para los municipios, que sólo canalizaban los servicios. No obstante, a partir de 2007 se inició el traspaso de la operación del Programa Puente a los municipios.

La paradoja del Sistema Chile Solidario es que, por una parte, pone a las familias en el centro de la política, obligando al Estado a responder a sus necesidades, cumpliendo estándares mínimos. Sin embargo, a pesar de ello, no estimula la participación de esos mismos sujetos en la construcción ciudadana, quedando la satisfacción de necesidades en manos de la administración pública. Es decir, se escinde la agenda de pobreza respecto de la participación ciudadana (Contesse y Delamaza 2005).

Este sistema representa una innovación importante en el modo de implementar las políticas sociales que ha predominado durante las últimas dos décadas, especialmente en cuanto supone una articulación intersectorial de los servicios estatales y establece una garantía explícita de prestaciones para la población considerada como de extrema pobreza. Es el propio agente estatal el que busca a los beneficiarios, familias previamente 
identificadas a través de la Ficha CAS (Ficha de Caracterización Socioeconómica, luego denominada Ficha de Protección Social). Una vez establecido el contacto, diagnosticada la situación y firmado el contrato, el apoyo familiar se responsabiliza de dinamizar la oferta estatal pertinente. La atención garantizada a que el Estado se compromete es sin duda el aspecto más innovador, y se liga a una concepción de derechos, aunque carece de una formulación universalista, conceptualizándose más bien en términos de focalización, integración social y equidad. De algún modo los derechos garantizados del Programa están aún mediados por la concepción focalizada de los programas contra la pobreza y por lo tanto no pueden formularse de un modo universalista.

Las innovaciones están limitadas, por otra parte, por la escasa transformación institucional de las políticas y programas públicos, pues el programa no innova ni en el contenido ni en el modo de definir las prestaciones que el Estado ofrece, ni en las modalidades institucionales de gestión de la política social. Mantiene y profundiza el enfoque de focalización sobre la base de la línea de la pobreza (acotándola aún más a la línea de la indigencia) y confía más en la habilitación de los pobres para actuar en el mercado y acceder a los servicios sociales que en la transformación de dicho mercado en un sentido de mayor inclusividad social.

El diagnóstico mismo de pobreza dura que fundamenta el sistema se ha basado en una definición estática de la pobreza, que es cuestionada por la primera Encuesta Panel encargada por MIDEPLAN que compara 1996 con 200 I y que muestra la extrema movilidad de las familias en pobreza (Castro y Katz 2004: 7). Una comparación de las Encuestas Panel entre I 996 y 2006 confirma el diagnóstico de que la pobreza no es un nicho estático, pues a lo largo de io años algunos permanecen en ese estado (pobreza crónica), mientras otros entran y salen de ella (pobreza transitoria). El primer grupo representa sólo 4,6\% de las personas, de acuerdo a las tres mediciones de la Encuesta CASEN del período. El segundo grupo asciende a 3I,2\% de las personas encuestadas, pero no son objeto del programa (Arzola y Castro 2009: 73).

El desarrollo posterior de Chile Solidario bajo la administración Bachelet consistió en promover una Red de Protección Social que incorporara otras prestaciones sociales, especialmente atención preescolar y garantía y mejoramiento de las pensiones mínimas. La garantía de derechos sociales, económicos y culturales no se expresa aún en un reconocimiento constitucional ni obliga al mercado, sino que principalmente incrementa las prestaciones y la asistencia estatal. Tras estas iniciativas de protección social y la consideración de los riesgos y vulnerabilidades que hacen que 
una persona o familia disminuya sus ingresos y sea considerada pobre está presente el diagnóstico dinámico y no estático de la pobreza.

El programa manifiesta una ambivalencia con respecto a su modo de abordar los temas de ciudadanía y participación social: su diseño y formulación omiten cualquier referencia a la ciudadanía, no cuenta con mecanismo alguno de participación social en las diferentes etapas del proceso y su diseño es claramente vertical (top-down). A pesar de ello, sus objetivos incorporan elementos propios de la ciudadanía social, enfatizando en aspectos de lo que se denomina ciudadanía pasiva, es decir, el reconocimiento efectivo de los derechos formalmente consagrados en los textos legales. La ambigüedad se debe a la tensión no resuelta de los enfoques basados en derechos con las visiones tecnocráticas al interior del gobierno -aún en sus técnicos sociales-, por lo que se omiten aspectos relacionados con la deliberación social y la descentralización ligados a la llamada ciudadanía activa. Por otra parte, introducir enfoques participativos implicaría poner en debate y diálogo social la protección frente al riesgo y la redistribución del bienestar para el desarrollo, que son justamente las áreas no tocadas de la política social chilena.

El sistema se inspira en una concepción de derechos sociales que busca que se hagan extensivos a las familias de extrema pobreza, aunque, como otros estudios han observado, "esto no significa que dentro de los objetivos específicos del sistema se incluya fortalecer la ciudadanía, ni tampoco haya una definición explícita de ella en el diseño. De hecho, ninguna de estas cosas ocurre" (Ruz y Palma 2005: 97). Al asociar la entrega de beneficios monetarios al cumplimiento de ciertas actividades comprometidas por la familia, se va más allá de la concepción pasiva de la ciudadanía, acercándose a los parámetros de la ciudadanía activa, aunque a través de una condicionalidad, lo que contradice la noción de derechos sociales (Sepúlveda 2009).

Según el sociólogo chileno Vicente Espinoza:

...la mayor innovación que presenta Chile Solidario, sin embargo, consiste en introducir 'derechos-contrato' [...] Esta forma de encarar la integración de los más desaventajados dignifica y legitima al grupo que recibe el apoyo, porque demuestra empíricamente su voluntad de integración. La solidaridad se plantea entonces como una medida correctiva de una desigualdad, sin victimizar al grupo beneficiario (2004: 176).

Las limitaciones a la noción de ciudadanía en el sistema son variadas. Por una parte, está su carácter implícito y, por otra parte, su formulación focalizada, que sujeta el acceso a derechos a la identificación administrativo- 
técnica de los beneficiarios y la participación en un formato estandarizado de atención. La determinación de las condiciones mínimas que se consideran aceptables para que una familia pueda egresar del programa fue estimada al margen de cualquier debate público de carácter político o técnico sobre ellas. Su definición, en efecto, fue resultado de negociaciones entre agencias del Estado y versó sobre modalidades de implementación, y no sobre el contenido de las prestaciones o condiciones mínimas. No fueron consultados ni los beneficiarios, ni los ejecutores, municipios y profesionales que actúan como apoyos familiares.

A diferencia de lo que ocurrió en el gobierno de Ricardo Lagos, a poco de iniciarse la administración de Bachelet, se realizó un amplio proceso de consulta -incluyendo actores políticos, técnicos, instituciones locales y beneficiarios- sobre las modificaciones que se establecerían en la Ficha de Caracterización Socioeconómica, que pasó a denominarse Ficha de Protección Social. (MIDEPLAN 2006). A pesar de ello, el Ministro de MIDEPLAN del gobierno de Piñera, Felipe Kast, anunció en 2010 una nueva modificación de la Ficha de Protección Social, lo cual indica la débil institucionalización de este tipo de mecanismos. En este diseño, la agenda de superación de la pobreza se reduce al acceso de los indigentes a la red pública, disociándose de la agenda de participación ciudadana, que fue canalizada mediante un proyecto de ley sobre asociaciones voluntarias, aprobado a comienzos de 2010 .

El gobierno de Bachelet se planteó ampliar el Sistema Chile Solidario hacia un Sistema de Protección Social por medio de un programa dirigido a incrementar significativamente la atención al nivel preescolar (Sistema Chile Crece Contigo) a las personas viviendo en situación de calle y a los adultos mayores a través de la reforma previsional, que entró en vigencia a mediados de 2008. Esta reforma asegura a todos los ciudadanos una pensión básica, independientemente de su capacidad de aportar durante su vida laboral, e incorpora a las mujeres que no han realizado actividad remunerada. Esta medida se inspira más claramente en una noción de ciudadanía universal. Este cambio podría indicar una nueva vinculación entre programas innovadores y política social tradicional, articulados bajo el concepto de protección social. Eventualmente, dicho concepto podría superar las principales limitaciones mostradas por los programas innovadores (MIDEPLAN 2004). El Sistema Intersectorial de Protección Social a la Infancia Chile Crece Contigo fue promulgado el I de septiembre de 2009.

La agenda de política social innovadora dirigida a la extrema pobreza ha permanecido sin contraparte social organizada durante todo el período estudiado. Ha evolucionado desde una concepción de trabajo 
con comunidades organizadas a nivel microlocal hacia un énfasis en las familias, desvinculadas de su red social de pertenencia y seleccionadas según su ubicación en las encuestas de pobreza. Su flexibilidad le ha permitido estimular diferentes dinámicas de organización para enfrentar problemas barriales y locales, pero no ha podido abordar las variables estructurantes de la pobreza de sus beneficiarios, ni potenciar su participación más allá de la ejecución de obras y programas barriales.

En síntesis, a través del Programa Puente y el Sistema Chile Solidario se ha logrado manejar la tensión entre los enfoques en la política contra la pobreza: los subsidios focalizados nacidos durante el gobierno militar, las concepciones de movilización de los recursos de los propios sectores afectados y el énfasis reciente en protección social a partir del manejo social del riesgo. A partir de ese diseño posteriormente se amplió la oferta estatal de servicios, expresada en el Sistema de Protección Social, que avanza en nociones de derechos sociales garantizados.

La noción de ciudadanía no aparece con fuerza en las orientaciones de estas políticas y programas, prevaleciendo las nociones de superación de la pobreza, habilitación social o igualdad de oportunidades. Durante el gobierno de Bachelet se produjo un nuevo desplazamiento hacia la noción de protección social. En todos estos términos se presupone un mercado laboral al cual las personas se incorporan una vez que han logrado ciertas condiciones mínimas que les permiten actuar por sí mismas. La construcción de ciudadanía -como categoría política con connotaciones de participación deliberativa en lo público- no forma parte de la orientación de estos programas. Incluso con la implementación del Sistema Chile Solidario, basado parcialmente en un enfoque de derechos, la ciudadanía se restringe a un asunto de agencia individual, expresada básicamente en el acceso a beneficios públicos y mayor autonomía para emprender o emplearse. Por cierto, esta última orientación se fortaleció en la administración de Sebastián Piñera, que enfatiza en el acceso a mayores oportunidades.

\section{RECONSTRUYENDO CIUDADANÍA A TRAVÉS DE REFORMAS INSTITUCIONALES CON ENFOQUE DE DERECHOS: EL CASO DE LA SALUD}

Los sectores tradicionales de la política social -salud, educación, vivienda y previsión social-fueron priorizados en materia de recursos a partir de I990, principalmente para la construcción y mejoramiento de infraestructura, el aumento de coberturas de atención y los salarios del personal. Sin embargo, no modificaron la institucionalidad establecida por el régimen militar en cuanto a la asignación de recursos, la participación del sector privado, 
la municipalización de los servicios y las regulaciones legales (Delamaza 2005, Fernández y Ochsenius 2006).

No se revirtió la municipalización de la atención primaria en salud y de los establecimientos educacionales, ni se reconstruyó el Servicio Nacional de Salud. Tampoco se alteró el sistema de subvenciones educacionales y la asignación del presupuesto de salud por atención brindada. A la vez, se mantuvieron las Instituciones de Salud Previsional (ISAPRES) en manos privadas, que atienden al sector de mayores recursos. Lo mismo ocurrió con la educación particular subvencionada, financiada por el Estado pero administrada por particulares. En esta coexisten organizaciones sin fines lucrativos, principalmente ligadas a congregaciones religiosas, con los empresarios de la educación, que también administran escuelas y liceos. En estos sectores, entonces, los modelos innovadores de relación con la sociedad civil no se reflejaron en una nueva institucionalidad social, sino que se radicaron en programas específicos, de bajo impacto institucional y político y no articulados claramente con las metas generales del sector.

Las diferencias son muy grandes entre los sectores. Mientras salud ha desarrollado una gran cantidad y variedad de programas e iniciativas, educación carece casi de avances. En el sector salud, por ejemplo, se crearon el Programa y el Fondo de Salud con la Gente (I 995), el Programa de Consejos de Desarrollo de Hospitales (1995), los Comités de Usuarios FONASA (1997) y múltiples programas dirigidos a sectores específicos de la población que consideran instancias de participación. También se abrieron instancias de información y debate público en torno a la reforma sectorial (200I), las Oficinas de Información y Reclamos y la Unidad de Participación (2002) y los Consejos Intersectoriales de la Red Asistencial, establecidos por la reforma en todos los servicios regionales (Fernández 2006: 40).

En educación, en cambio, recién en 2005 se establecieron los primeros Consejos Escolares en las escuelas, regulados por ley. Son mecanismos de participación del conjunto de la comunidad escolar, pero carente de atribuciones en las decisiones del establecimiento educacional. La presentación oficial del Ministerio de Educación de los materiales de apoyo para la constitución de los consejos, señala: "El Consejo tendrá atribuciones de tipo consultivo, informativo, propositivo y resolutivo (sólo cuando el sostenedor así lo determine)". Luego de sintetizar las materias acerca de las cuales debe ser informado y consultado, agrega: "Importante: el Consejo Escolar no tiene atribuciones sobre materias técnico pedagógicas, las que son de responsabilidad del equipo directivo o de gestión" (Ministerio de Educación 2005. Subrayado en el original). 
Contrasta esa institucionalidad con sus similares en países como España, donde el Consejo Escolar participa de la selección de los directores, aprobación del presupuesto y múltiples otras decisiones de la escuela (Martínez 1996). También difiere sensiblemente de sus homónimos en Argentina y Brasil, que cumplen funciones de orientación de las políticas educativas a nivel local y se articulan con las instituciones públicas correspondientes.

En general, la corriente participativa evolucionó en los márgenes de la institucionalidad social tradicional, apoyada en ocasiones por proyectos de cooperación internacional. Sin embargo, en el caso de la salud, después de 2000 se implementó una reforma institucional basada en el enfoque de derechos, operacionalizado a través del enfoque de garantías sociales, que reintroduce nociones del universalismo en la política social que no habían estado presentes hasta ese momento. El enfoque de derechos se funda en la universalidad y progresividad de la realización de los derechos económicos, sociales y culturales. Unido a esto, la literatura identifica diversos ámbitos de principios que orientan las políticas basadas en este enfoque: identificación de los pobres, equidad, no discriminación, participación y empoderamiento, rendición de cuentas y transparencia al nivel conceptual y de prácticas (Nyamu-Musembi y Cornwall 2004, Abramovich 2006, Sengupta 2006).

En el caso chileno, si bien dicha reforma se basa en un enfoque de derechos ciudadanos, su implementación se realizó de acuerdo con un modelo top-down y sin vinculación con los programas innovadores dirigidos a la sociedad civil que el propio sector llevaba a cabo. Sin embargo, tanto el enfoque de derechos como el énfasis del sector salud en la participación ciudadana llevan a una necesaria reformulación de las metas del sector y la integración de los esfuerzos, abriendo el debate sobre los mecanismos institucionales aptos para ello. De este modo, se transita de una problemática más bien marginal o accesoria a una que forma parte de la corriente principal de la reforma del sector.

Junto con analizar las concepciones básicas tras la reforma de la salud, es necesario considerar la cultura organizacional del sector. En la promoción de esta reforma jugaron un papel clave actores que permanecieron en el sector con algún grado de poder, aún luego de aplicadas las reformas privatizadoras de los ochenta. También se debe relevar la existencia de una masa crítica profesional y de usuarios del sistema que le otorgaron a este sector una dinámica diferente a la ocurrida en educación, por ejemplo. La formación de esta masa crítica se relaciona con algunos rasgos aún vigentes de la práctica institucional histórica de inserción social de la salud estatal vigente desde I952, cuando se creó el Servicio Nacional de Salud. El sector 
salud es un caso claro de existencia de las diferentes capas geológicas del Estado. De acuerdo a un analista de la modernización en Chile, se trataría de la remanencia de proyectos modernizadores del pasado en el Estado chileno actual (Van der Ree 2007).

Sin embargo, el Estado no actúa solo y la reforma debe contender, y negociar, con los poderosos intereses privados presentes en el sector. Las ISAPRES, aseguradoras privadas de salud que cubren al 20\% más rico de la población, defienden la salud lucrativa. El Colegio Médico defiende la salud pública, pero también sus prerrogativas corporativas y su libertad en el mercado. Los demás gremios de la salud, que sólo laboran en el sector estatal, son también actores incidentes en materias laborales y de defensa de un modelo de salud pública con preeminencia del Estado. En contraste con las políticas de pobreza, aquí se trata de un sector con presencia de múltiples actores dentro y fuera del Estado (Puentes 20 Io), que son fuente de disensos y consensos, como ocurre en los discursos del Ministerio de Salud, el Colegio Médico y los gremios profesionales de la salud sobre la reforma, los que son analizados en Quiero (2005).

Lo anterior lleva a reconstituir la genealogía de la política del sector, analizando la divergencia existente hasta hoy entre el enfoque de derechos y el enfoque de participación al interior del mismo sector y las dificultades de integración de los mismos en un contexto de sistema mixto (público/ privado) de salud. Nuevamente se puede establecer aquí el contrapunto con el sector educación, que aparece como un sector sin tradición ni cultura organizacional de vínculo con la sociedad civil, sin proceso ni proyecto de reforma institucional y sin programas ni mecanismos de participación ciudadana relevantes, en un diálogo y negociación basados en temas reivindicativo-gremiales con el Colegio de Profesores.

La reforma de la salud se inscribe en un movimiento general en América Latina, en cuya evolución influyen la debilidad o fortaleza de la construcción histórica del Estado, el grado de apertura a la participación del sistema privado en las prestaciones o en el aseguramiento, la magnitud de la pobreza, los grados de exclusión y los niveles de desigualdad existentes en los diversos países. En Chile, la reforma tiene un enfoque global que enfrenta parcialmente las consecuencias de la reforma privatizadora de I98 I y que toma como referencia algo de los modelos de los distintos países de la región (Aedo 200I, Annik 2005). Apunta a revertir los cambios neoliberales impulsados en los ochenta, que socavaron las bases de solidaridad y universalidad, desconcentraron las funciones de salud y debilitaron severamente al sector público estatal, dejando a los ciudadanos frente a la emergencia de un mercado privado con prestaciones de mejor calidad pero sometido a regulaciones mínimas (Sojo 200 I, Fernández y 


\section{Ochsenius 2006).}

Las correcciones realizadas durante noventa, asociadas a políticas e instrumentos de recuperación y mayor eficacia en la gestión, no conllevaron necesariamente el mejoramiento de la calidad de las políticas ni a la resolución de las desigualdades sociales, lo que desencadenó nuevos procesos de transformación para construir mayores equilibrios sociales hacia finales de la década. La reforma introduce regulaciones que establecen fines y metas de efectividad tanto para el mercado como para la institucionalidad pública en su calidad de prestadores de servicios de salud. Establece el GES, es decir, garantías exigibles -incluso judicialmente- que se aplica a conjuntos cada vez más amplios de las patologías prevalecientes en la población (Arrau 2002, Erazo 2004).

Lo novedoso del enfoque es que reintroduce la noción de derechos universales del cual se había alejado la política social desde los ochenta, al adoptar el enfoque de focalización. El Estado compromete la atención de un conjunto de patologías de acuerdo con ciertos protocolos de tiempo, costo y calidad y se obliga a buscar y financiar la atención privada si no logra cumplir su compromiso. El hecho que el Estado esté obligado a comprar servicios al sector privado cada vez que no pueda cumplir con lo comprometido fue el factor que neutralizó la oposición del sector de la salud privada, pues le creó un enorme nicho de negocios para ésta.

No toda la reforma propuesta fue aprobada por la oposición de derecha en el parlamento, limitando sus alcances. Los dos cuerpos legales no aprobados fueron el Fondo Solidario, que reformaba el carácter puramente individual del seguro de salud, y el Estatuto de Derechos y Deberes del Paciente, que fortalecía la condición de los ciudadanos y ciudadanas (Fernández y Ochsenius 2006). Resulta paradojal que la determinación de las prioridades y el establecimiento de las garantías haya sido un proceso conducido y realizado por técnicos de la salud, sin participación de la ciudadanía. Es decir, se avanza en el fortalecimiento de la ciudadanía con resguardo jurídico, pero se hace prescindiendo de su participación.

También hubo modificaciones en la gestión, incorporando la promoción y prevención en salud, el enfoque de salud familiar, el seguimiento a lo largo del ciclo vital de las personas y familias, la gestión en red entre los niveles de atención y los procesos de participación ciudadana en el desarrollo, seguimiento y control de la política pública. Se retoma la descentralización de funciones mediante la nominación de autoridades sanitarias regionales con la participación de consejos consultivos y el impulso de la autonomía hospitalaria mediante experiencias piloto (Aedo 200I, Fernández y Ochsenius 2006, Vergara 2007). 
El contexto de reforma institucional establece posibilidades diferentes para la participación ciudadana y el nexo con la sociedad civil, apuntando a una mayor institucionalización e impacto. Este aspecto fue considerado parcialmente en el diseño de la reforma. Sin embargo, la presión por instalar nuevos mecanismos de participación surge desde la propia dinámica de la reforma y en diversos ámbitos. En primer lugar, el hecho mismo de que el sistema de garantías explícitas de salud establezca derechos exigibles abre la posibilidad de que ellos efectivamente se exijan. Una vía posible es la acción judicial que, evidentemente, incrementaría exponencialmente los costos del sistema. Generar vías de participación que aseguren un mejor funcionamiento del sistema en su conjunto se transforma en un interés de los propios servicios de salud, descontando el hecho de que normalmente debe ser algo considerado dentro del enfoque de derechos. Por otra parte, un interesante conjunto de experiencias locales ha adelantado y operacionalizado varias de las metas globales señaladas por la reforma, transformándose algunas de ellas en referentes para el sector (Fernández y Ochsenius 2006, Fernández 2007).

La evaluación de medio término de las metas sanitarias 2000-20io realizada en 2005 indicó un alto nivel de cumplimiento en relación a la atención médica, vacunación y cobertura del sistema en general. Sin embargo, en relación a la prevención y las conductas de las personas, los resultados son altamente deficitarios (obesidad, alcoholismo, adicciones a sustancias peligrosas, conductas de riesgo, salud mental, salud ambiental, etc.). Esto lleva a reorientar los esfuerzos en dos sentidos: mejorar e incrementar las regulaciones para brindar un marco de protección efectivo en relación con los llamados determinantes sociales de la salud, e intensificar los mecanismos de involucramiento y participación de la población en general y de los otros sectores de política pública relevantes, como educación, medio ambiente y trabajo (Ministerio de Salud 20 io).

El gobierno de Bachelet profundizó la participación ciudadana en el sector salud. De una concepción inicial limitada al fortalecimiento de las Oficinas de Información y Reclamos, orientada al mejoramiento de la gestión de problemas no resueltos, se pasó a incorporar diferentes mecanismos de participación organizada de la comunidad. En la práctica, estos mecanismos están formados mayoritariamente por usuarios directos del sistema, pero algunas experiencias transitan hacia una composición más amplia. Un ejemplo de ello es el Consejo Consultivo de Salud de Coquimbo, que lideró la demanda por un plebiscito comunal, siendo el primer caso en Chile que ha logrado cumplir el alto requisito de firmas y protocolos exigidos por la ley para obligar al municipio a convocar a plebiscito $^{6}$.

6 http://www.innovacionciudadana.cl/portal/despliegue.php?ID_ 
Es interesante el caso de los presupuestos participativos en salud. Surgidos como una adaptación de la metodología brasileña a la gestión del Servicio de Salud de Talcahuano, fueron adoptados como política nacional por el Ministerio y puestos en práctica en gran cantidad de otros servicios del país (Fernández 2007, Delamaza y Ochsenius 2008). Este proceso se refuerza en el plano institucional con la conformación de unidades de participación en todos los servicios y la capacitación de funcionarios.

El cambio de gobierno en 20 Io representó un traspié para el incipiente desarrollo de la política de participación en salud, puesto que la nueva prioridad es la introducción de mecanismos de gestión privada en el manejo de los hospitales y la reducción de su deuda. También se ha anunciado la idea de trasladar al usuario la opción por atenderse en el sistema privado o público. La unidad encargada de participación fue desactivada, gran cantidad de funcionarios fueron despedidos y es incierto el desarrollo futuro de las iniciativas de participación.

La reforma de la salud muestra un proceso en curso, cuyo énfasis inicial fue la recuperación del enfoque de derechos y la búsqueda de un nuevo acuerdo con el sector privado, sin modificar el esquema mixto que ha regido al sector salud. Su forma de implementación fue top-down, marcando la paradoja de reformas con contenido ciudadano pero impuestas desde arriba. Sin embargo, los requerimientos que la reforma plantea en el marco de las metas sanitarias concordadas para el nivel de desarrollo del país y la persistencia de cierta voluntad participativa en la tradición institucional y entre los funcionarios han abierto espacios relevantes para la formulación de políticas en el área. Éstas aún se limitan mayoritariamente a los usuarios directos, pero transitan hacia formas más amplias, vinculantes y públicas de participación ciudadana.

\section{EL COMPLEJO INTERFAZ SOCIO-ESTATAL EN EL ÁMBITO LOCAL}

Los rasgos principales del proceso de descentralización posterior a 1990 revelan varias características del modelo de gobernabilidad. Se recuperó la capacidad de elegir a los alcaldes y concejales de las comunas, es decir, la estructura política de la administración comunal. Sin embargo, no se modificó sustancialmente la arquitectura institucional del municipio, manteniéndose la municipalización de los servicios traspasados por el régimen militar y la estructura interna de la municipalidad.

En cuanto a las modalidades de participación institucional, sólo se adaptaron los mecanismos creados en los ochenta de tipo semi-corporativo:

SECCION=I I \&ID_CONTENIDO=56. Consultado el 6 de septiembre de 2008 . 
se pasó de los Consejos de Desarrollo Comunal (CODECO) a los Consejos Económico Sociales Comunales (CESCO). Se crearon los CORE, un nivel de administración regional basado en la democracia indirecta y dotado de débil legitimidad. El traspaso de recursos para la inversión, sin embargo, fue creciendo y se entregó a las intendencias -que representan al Presidente de la República en la región subrayado en el original plantas profesionales denominadas Gobiernos Regionales (GORE). Los GORE y los CORE se constituyeron en interlocutores técnico-políticos de la política pública, planteando desafíos de participación ciudadana, de efectividad en la gestión regional y de articulación de los niveles de la administración.

\section{Chile, la descentralización eXCePcional en América Latina}

Chile se ha caracterizado por una estructura política centralizada que ha subsistido a distintas iniciativas descentralizadoras y federalistas, especialmente durante el siglo XIX. Las fracciones liberales, partidarias de una mayor distribución del poder entre Santiago y las otras provincias, fueron derrotadas en el campo de batalla en i 828, i 85 I y i 859 (Salazar y Pinto 1999). A partir de 1925, los esfuerzos descentralizadores se orientaron según la idea de fomentar el desarrollo económico del país, pero han dejado de lado la descentralización política, es decir la redistribución del poder entre el centro y las regiones, provincias y comunas (Angell I999, Montecinos 2005b).

Chile, entonces, representa una situación excepcional en América Latina, pues la descentralización no ha estado asociada a la liberalización y democratización política. Tal como plantea el analista inglés Alan Angell, "incluso en los momentos de máxima crisis política en Chile, ha habido muy poco cuestionamiento al Estado central, y la defensa de la descentralización no ha sido propuesta por ningún bando como medio para controlar la crisis" (I999: I35). La afirmación de Angell es válida especialmente a partir de I 859, donde no vuelve a haber rebeliones regionalistas. Lo que sí hay es un conjunto de iniciativas comandadas por los técnicos del poder ejecutivo desde mediados de los ańos sesenta para establecer medidas tendientes a un desarrollo más equilibrado (Montecinos 2005b). Esa misma orientación es retomada por el gobierno militar, agregándole la preocupación por el poblamiento del territorio, el control de fronteras y otras condiciones de carácter geopolítico. La tecnocracia militar asumió, con ligeras modificaciones, la propuesta desarrollista de dividir el país en un número menor de regiones, terminando así con la organización político administrativa tradicional de las 25 provincias.

La propuesta elaborada por los desarrollistas durante el gobierno de Frei Montalva era de dividir el territorio en once regiones y un Área 
Metropolitana, de acuerdo a criterios de desarrollo y la existencia de un polo urbano o cabecera de región, junto a un espacio rural relacionado (Boisier 2000, Montecinos 2005b). Los técnicos de ODEPLAN que habían trabajado en esa división regional en los sesenta permanecieron colaborando con el gobierno militar y sus propuestas fueron recogidas por los militares de pensamiento geopolítico. Serán más o menos los mismos técnicos los que se hicieron cargo de materias descentralizadoras en los gobiernos de la Concertación, como Sergio Boisier, Esteban Soms, Juan Cavada, entre otros (Boisier 2000).

Al momento del golpe militar, Chile estaba dividido en 25 provincias que habían sido creadas paulatinamente según las pautas de poblamiento del territorio a partir de la Constitución de 1925 y que cubrían todo el territorio nacional (Montecinos 2005b). El planteamiento desarrollista de los sesenta de crear macro regiones de desarrollo no pretendía necesariamente terminar con la estructura política de las provincias, sino que agruparlas en función de criterios de desarrollo económico. El régimen militar, asumiendo en gran medida esa propuesta, la convirtió en un nuevo ordenamiento político-administrativo. De once macro regiones y una Zona Metropolitana, se llegó en I 976 a doce y una Región Metropolitana.

Obviamente, durante ese período el régimen no contendía con intereses políticos, ni consideró las variables de representación. Dos provincias que perdieron su calidad de tales, así como su condición de capital regional, lograron constituirse como regiones en 2009: Los Ríos (antigua provincia de Valdivia) y Arica-Parinacota (antigua provincia de Tarapacá). En el marco de su política de descentralización, que redujo las funciones del gobierno central, en I974 el régimen militar estableció las Secretarías Regionales de Planificación como organismos colaboradores de los Intendentes. Estas secretarías retornarían a MIDEPLAN en I990 y nuevamente a los gobiernos regionales a partir de 2005 (Secretaría de Planificación Metropolitana 2009).

Esto sucedía a la par con un férreo control del proceso político local, pues altos oficiales de las Fuerzas Armadas y Carabineros fueron designados a la cabeza de las regiones. Lo mismo ocurrió en las gobernaciones provinciales, mientras las alcaldías de las comunas fueron ocupadas por civiles proclives al régimen e igualmente designados. En un contexto político altamente restrictivo y controlado, se sustituyó un sistema político local surgido a través del desarrollo histórico -aunque centralista- por un sistema de administración orientado a metas geopolíticas y de desarrollo, surgido de un acto de voluntad política del gobierno de la época. El componente neoliberal se expresó en el traspaso de los servicios de salud y educación a los municipios con el fin de achicar el Estado central y desactivar las 
presiones sobre él.

La democratización post 1990 contempló sólo la reforma municipal, consistente básicamente en una reforma electoral para restaurar la autoridad local tradicional. En cambio, la reforma regional no estaba dentro de los planes del gobierno democrático, ni tampoco formaba parte de los planteamientos de la oposición. En la práctica, "la reforma regional, por su parte, ocurrió como un efecto no deseado de esta restauración (democrática comunal)" (Mardones 2006: I9). Según Mardones, en los hechos la constitución de los gobiernos regionales fue una concesión del gobierno a la oposición que buscaba recuperar por esa vía compensatoria la disminución de su poder en los espacios municipales, que se veía como algo inevitable. Eso la llevó a proponer la creación de un nuevo estamento, los CORE, donde compartiría el poder con la coalición gobernante, compensando de este modo la pérdida del monopolio que había tenido hasta 1992 en los Concejos Municipales (Boisier 2000, Mardones 2006).

El diseño de los CORE y los GORE no formó parte del proyecto democratizador ni estuvo sustentada en una concepción de reestructuración del poder político. Ha consistido en un esfuerzo por desconcentrar la inversión pública y modernizar el aparato del Estado. A ello se agrega el hecho de que la estructura del ejecutivo está orientada a garantizar el control político central -presidencialismo reforzado por la Constitución de $1980-$ y el control de la política económica. Por ello, de acuerdo con Angell, "en el gobierno no hay ningún agente autónomo que tenga poder y voluntad para profundizar el proceso de descentralización y contrarrestar el poder de los ministerios centrales" (I 999: I 45). De hecho, el organismo encargado de la descentralización es la Subsecretaría de Desarrollo Regional y Administrativo (SUBDERE), dependiente del Ministerio del Interior. Este ministerio no es, obviamente, un agente proclive a la descentralización del poder.

Por todo lo anterior es que a lo largo de todo el proceso post I 990, "la necesidad de incorporar la descentralización en la agenda política inmediata, era más bien nimia... [por lo que] fue más una reforma administrativa que una reforma gubernamental" (Angell 1999: 136). En este mismo sentido se pronuncia José Antonio Abalos (1993), otro especialista en el tema. Es una descentralización orientada según los requerimientos del diseño del modelo de gobernabilidad: una transición negociada por una elite reducida que requería mantener el control central del proceso, un alto protagonismo de los técnicos por sobre la deliberación ciudadana, una democracia de baja intensidad con pequeños márgenes de incertidumbre y un conjunto de políticas sociales exitosas que restaron fuerza al argumento descentralizador por motivos de equidad. 


\section{LA GESTIÓN MUNICIPAL}

El proceso descentralizador, inicialmente top-down, ha favorecido no obstante la emergencia de actores subnacionales, especialmente los municipios, así como una demanda creciente por democratización de los gobiernos regionales. En septiembre de 2009, por ejemplo, el parlamento aprobó la modificación constitucional que permitirá la elección directa de consejeros regionales en 2012 , en conjunto con las elecciones municipales ${ }^{7}$. De concretarse dicha elección -aún falta la ley que la regule- entre la primera y la segunda reforma democratizadora a nivel subnacional habrán pasado veinte años.

Pero mientras los gobiernos regionales mantienen una estructura separada de la sociedad civil, los municipios han experimentado un desarrollo que los ubica como uno de los espacios en donde se produce dicha relación y se evidencia un cierto modelo o tendencia de vinculación entre política social y ciudadanía. El nivel municipal ha adquirido una creciente importancia para la ejecución de programas, canalizando gran cantidad de recursos públicos. La descentralización ha sido un proceso que, con distintas características y ritmos, ha impactado a los espacios locales, brindándoles grados crecientes de autonomía y complejidad a su gestión. Diversas políticas y programas públicos han sido transferidos al ámbito local. El traspaso en I98I de los establecimientos de educación básica y media y los consultorios de salud primaria a los municipios generó un fuerte desfinanciamiento del sector (Rufián 2005). Los municipios chilenos representan, en términos de recursos, 2,8\% del PIB nacional y I $3 \%$ del gasto del gobierno general. El porcentaje promedio del ámbito local en los países de la OECD es de I4,8\% y en países de América del Sur y Central el porcentaje es de 6,4\%. Es decir, los municipios chilenos son el eslabón más pequeño de un gobierno también extremadamente pequeño (Garrido 2007).

Con la redemocratización política de los municipios en 1992, estos comenzaron a implementar diversos programas de la nueva agenda social. En I999, el municipio adquirió atribuciones nuevas en los ámbitos económico, productivo, ambiental y de igualdad de oportunidades. A la vez se han generalizado instrumentos de acción local como los Planes de Desarrollo Comunal, los Planes Reguladores y los Fondos de Desarrollo Vecinal, tecnificándose la gestión local. El gobierno central, con recursos del Banco Mundial, ha desarrollado sucesivos programas de fortalecimiento y modernización de las administraciones locales (Díaz I998, Montecinos 2007).

7 http://www.subdere.gov.cl/ I 5 Io/article-782 I 4.html. Consultado el I 8 de septiembre de 2009. 
Lo que no se ha modificado desde I 992 es la estructura de participación del municipio, expresada a través de los CESCO, un organismo de carácter consultivo, conformado con estamentos de dirigentes provenientes de organizaciones territoriales, funcionales y otras relevantes en las comunas. En realidad, el CESCO es una adaptación de los CODECO que el gobierno militar había diseñado de acuerdo con un modelo de participación corporativa y despolitizada (Díaz 1998, Greaves 2003). Sin embargo, estos organismos no cuentan con la suficiente legitimidad ante la población ni validación ante la autoridad y sus atribuciones son muy reducidas. En 2005 sólo I $9 \%$ de la población encuestada en seis regiones del país dijo conocer la existencia del CESCO en su comuna (Más Voces 2005). La aprobación de la Ley de Asociatividad en 20 Io, ha llevado a la sustitución de los CESCO por Consejos de Organizaciones de la Sociedad Civil, igualmente de carácter consultivo, a partir de 20 I I.

El municipio ha pasado a ser el referente de gran parte de la acción asociativa de los sectores populares, tanto en el campo como en la ciudad. Al carecer de estructuras de institucionalización, no se constituye como lugar de confluencia ni de articulación territorial de las demandas populares. Pero el municipio se convirtió en el lugar posible de reivindicación que emergió como resultado de las reformas estatales de I98 I y posteriores. Nos referimos al traspaso a las municipalidades de la salud y la educación; la administración de la red asistencial y los nuevos programas de política social canalizados a través del municipio.

Un estudio en dos comunas de Santiago indica que la actividad predominante de los dirigentes vecinales es concurrir al municipio, especialmente a la Dirección de Desarrollo Comunitario (DIDECO), en busca de respuestas a sus diferentes problemas, sin que ocurra lo mismo con otras instancias de los otros niveles del Estado (Greaves 2003). Sin embargo, la DIDECO es una estructura especializada en gestionar el vínculo con las organizaciones -como tramitar el reconocimiento jurídico- y en el otorgamiento de los beneficios asistenciales. Debido a esto, permanece desconectada de las instancias que procesan y atienden las problemáticas tradicionales de los habitantes: obras municipales, aseo, impuestos, permisos habitacionales, seguridad ciudadana y tránsito, entre otros. Más distantes están aún de las nuevas funciones municipales desde I98 I -salud y educación-, que en muchas comunas son administradas por corporaciones autónomas presididas por el alcalde, pero que carecen de un mecanismo de rendición de cuentas (accountability) y control por parte de la ciudadanía. Las DIDECO generalmente acogen las nuevas oficinas destinadas a grupos específicos, como mujeres, adultos mayores, jóvenes, las que sufren la misma limitación ya mencionada. 
La transferencia de funciones al municipio y el mayor vínculo y contacto con la comunidad, especialmente los grupos pobres de la comuna, producen como contrapartida una asociatividad múltiple, pero muy reducida en sus alcances y carente de interlocutores más allá de la propia DIDECO municipal. Los grupos poblacionales tienden a mantener una actitud peticionista con el municipio, que está lejos de las posibilidades del municipio satisfacer. A la inversa, desde la administración local impera el asistencialismo y formas de clientelismo, dentro de los márgenes que permiten los escasos recursos disponibles. No se ha desarrollado la fiscalización y el control ciudadano de las funciones gubernamentales en el nivel local. Los mecanismos establecidos por la ley son limitados y no hay una tradición ni una cultura al respecto tanto en las organizaciones como entre los funcionarios. En 1999 se estableció la obligatoriedad de dictar ordenanzas comunales de participación, que incluyen realizar cuentas públicas y algunos otros mecanismos para promover la transparencia en la gestión, pero no se han desarrollado metodologías que hagan de este instrumento un factor real de fiscalización ciudadana.

Una investigación sobre programas municipales con dimensión de género en la Región Metropolitana mostró que sólo en uno de ellos (Oficina de la Mujer de Lo Espejo) se habían desarrollado capacidades en las dirigentas para evaluar el presupuesto de la repartición y cotejarlo con el presupuesto municipal (Provoste y Valdés 2000). Experiencias como la Fiscalía Comunal de La Granja, implementadas a comienzos de los noventa, fueron discontinuadas y no han sido replicadas en otros lugares. Otras experiencias apoyadas directamente por la cooperación internacional no han tenido suficiente continuidad para lograr un impacto duradero (Hewitt 2004).

La institucionalidad municipal es homogénea en todo el país, lo que dificulta la posibilidad de organizar la participación de acuerdo con las tradiciones y estilos de cada localidad. Los municipios rurales, por ejemplo, resultan perjudicados, pues el modelo utilizado es urbano. Pero también hay una inercia política que se evidencia, por ejemplo, en el hecho de que si bien la ley municipal actual establece la posibilidad de reglamentar los CESCO y establecer ordenanzas de participación ciudadana según la realidad local, son muy pocos los municipios en que esto se ha puesto en práctica, y la mayoría de ellos lo ha hecho según el formato propuesto por la Asociación Chilena de Municipios. Lo que surge de allí será seguramente una participación que no compromete a una comunidad que no ha participado en su gestación. 


\section{LA INNOVACIÓN LOCAL}

El ámbito local se manifiesta como un campo en veloz transformación: la ampliación de funciones, los nuevos mecanismos de financiamiento, la mayor autonomía de los municipios indígenas y otros cambios son procesos que vienen ocurriendo en diversos lugares de América Latina. Se verificaron en Bolivia, con la Ley de Participación Popular en 1994, en México con las reformas en I 995 y I 999, y en Perú, donde en los últimos años se han establecido los presupuestos participativos como requisito para la obtención de recursos (Salman 1998, Oxhorn 2001, Remy 2005, Cant 2006). La agenda de las políticas públicas municipales ha ido expandiéndose significativamente en los ámbitos que cubre, las funciones de la administración, los actores participantes y los recursos involucrados. Se ha pasado desde una situación tradicionalmente restringida hacia una agenda ampliada y una integral (Cabrero 2004: 79). En la medida que la agenda crece y se complejiza, "va requiriendo la participación de más actores, es decir va siendo más densa" (Cabrero 2005: 75).

Un enfoque ciudadano para la gestión se insinúa en algunas experiencias innovadoras que fortalecen a la ciudadanía para deliberar y participar, sin sacrificar la efectividad de resultados, "ya que su dinámica y resultados dependen mucho de las competencias adecuadas de los actores para la tarea que emprenden" (Bebbington et al. 2005: I 4). La profundidad de la participación en un municipio o localidad no es sólo función de la fuerza de la movilización social. También son factores críticos la coherencia entre las atribuciones y la voluntad política de las autoridades, el financiamiento disponible en relación con la demanda, los vínculos, articulación y capacidad de negociación con las políticas hacia arriba, la capacitación de los funcionarios públicos, los instrumentos técnicos adecuados y las capacidades de las propias organizaciones y redes sociales (Bebbington et al. 2005: I 5).

La innovación municipal en Chile se produce en un contexto general que -como se ha expuesto- limita estos procesos. Sin embargo, se trata de una tendencia que persiste y se desarrolla en el tiempo a pesar de los obstáculos. Tomando como referencia cinco convocatorias al Premio Innovación y Ciudadanía entre I 999 y 2006, se constata que cerca de 30\% de las comunas del país tienen iniciativas innovadoras con un componente de fortalecimiento ciudadano (Delamaza y Fernández 2006). Entre ellas se encuentran diferentes tipos de municipios en cuanto a su tamaño, recursos económicos, zona geográfica y conducción política. Si bien un pequeño número de municipios son generadores de innovaciones múltiples $\mathrm{y}$ reiteradas, éstas se encuentran también presentes de una $\mathrm{u}$ otra manera en un rango mucho más amplio. Es decir, la emergencia de tendencias 
innovadoras con fortalecimiento ciudadano está presente de manera extendida en el país, pero a través de unidades específicas y a veces aisladas entre sí (incluso dentro de su propio municipio). Más que responder a hipótesis políticas consistentes, o apoyadas desde el Estado central, lo que existe es la iniciativa local, detrás de la cual actúan muchos funcionarios de distinto rango, alcaldes de distintas corrientes políticas, presencia de ciertos programas públicos y la tradición organizativa previa (Delamaza y Fernández 2006).

En Chile, la iniciativa local innovadora se asocia claramente a las nuevas funciones que, en combinación con el gobierno central y/o grupos de la sociedad civil, se reflejan en programas y oficinas municipales específicas de reciente creación: desarrollo productivo, medio ambiente, mujeres, jóvenes, etnias. De la política local de los noventa surgió también la planificación participativa, expresada tanto en los Planes de Desarrollo Comunal (PLADECO) como en áreas específicas de planificación.

Una de las dificultades para la proyección de estas experiencias es el insuficiente desarrollo de una concepción de municipio ciudadano que redefina la relación tradicional del municipio con la ciudadanía. Aún persiste el modelo populista clientelar de relación entre municipio y comunidad, fortalecido durante el largo gobierno militar. Este tipo de relación se ha proyectado a través de la figura de los alcaldes caudillos de su comunidad, favorecida por la legislación que concentra el poder en la autoridad superior del municipio. El caudillismo es más fuerte en comunidades en crisis, amenazadas por las macro tendencias de la modernización económica, y en comunas aisladas con grandes debilidades en el ámbito productivo, en las cuales el alcalde se erige como defensor de la comunidad, mientras dispensa favores y beneficios en función de la lealtad absoluta hacia su gestión. Un estudio en I 5 municipios reveló la persistencia de este modelo en varios de ellos, especialmente comunas pequeńas con liderazgo tradicional, apenas impactadas por las iniciativas de política social de la administración central, más allá de la red de subsidios (Cannobio y Jeri 2007). También Stephanie Alenda (2004) analizó cuatro experiencias innovadoras, donde se evidencian los múltiples problemas de introducir la participación ciudadana en contextos previamente clientelistas.

También ha surgido fuertemente el modelo gerencial basado en la idea del municipio como administrador eficiente de servicios, que predomina en las iniciativas de modernización municipal impulsadas por el gobierno y que no contempla el fortalecimiento ciudadano (Montecinos 2007). El modelo gerencial es muy compatible con el planteamiento de despolitización de las decisiones públicas y los enfoques de modernización de la gestión, lo que en la práctica supone la subordinación a las tendencias dominantes del 
entorno económico. Las orientaciones están enfocadas a la racionalización del uso de los recursos y a garantizar una atención eficiente de los clientes. La introducción de métodos empresariales en la gestión municipal es una expresión de la tendencia general en la administración pública, que da por supuesta la existencia de un campo democrático consolidado y la vigencia de derechos ciudadanos garantizados en diversos ámbitos. Varias de las innovaciones se enmarcan en la concepción gerencialista de la modernización pública.

$\mathrm{Al}$ respecto el cientista político Egon Montecinos (2007) compara dos metodologías definidas en el papel como participativas, el PLADECO y los presupuestos participativos, descubriendo más diferencias que semejanzas. Los PLADECO están inspirados de hecho en la concepción gerencial de la modernización municipal, mientras los presupuestos participativos cuentan con un enfoque de empoderamiento ciudadano. La misma concepción gerencial está presente en el modelo de calidad de servicios que se utiliza de base para el Sistema de Acreditación de Calidad de los Servicios Municipales desarrollado por la SUBDERE, en el que el ciudadano se considera un usuario(a) individual, que el modelo denomina cliente. La gestión acreditada debe conocer al usuario, informarlo, asegurar su acceso y atención, gestionar sus reclamos y sugerencias y medir sus niveles de satisfacción (SUBDERE 2007: 22).

Sin embargo, también existen innovaciones que incorporan la dimensión deliberativa y el control social como factores de construcción democrática a través de la participación desde el diseño de las iniciativas, redefiniendo las formas de gestión. Todos los presupuestos participativos originados en Brasil han tenido como antecedente la reestructuración geográfica del territorio, con su correlato en la forma de administración. En el caso de la ciudad de Porto Alegre, hubo un debate entre la administración y los movimientos sociales acerca de la lógica de la división en regiones para las asambleas del presupuesto, primando la de los movimientos organizados. Las experiencias más desarrolladas de presupuesto participativo negocian también las reglas del juego de la elaboración del presupuesto y no solamente la destinación de una parte de los recursos a la deliberación popular. En Porto Alegre, después de cada ciclo presupuestario, el Consejo del Presupuesto Participativo se reúne para evaluar la gestión y establecer modificaciones al procedimiento empleado (Avritzer 2002).

Desde otro punto de vista, los presupuestos participativos han sido destacados como una herramienta para involucrar a los sectores tradicionalmente excluidos de las decisiones locales en las decisiones presupuestarias. Encuestas realizadas en Porto Alegre entre los participantes de las asambleas muestran que estos tienen un perfil más pobre, más 
femenino y de menor nivel educacional que la media de la población (Avritzer 2002). Al introducir mecanismos de delegación, como la elección de representantes, esa inclusividad se debilita, debiendo constantemente capacitar a líderes y promover y ampliar la participación para evitar la constitución de nuevas elites. La experiencia internacional comparada indica que bajo el rótulo de presupuesto participativo se esconden realidades muy diversas y que las más desarrolladas responden a fuertes estímulos, tanto de la participación social como de la formación y recalificación de los funcionarios municipales (Blanco 2002, Filgueiras 2005, Sintomer 2005, Velásquez 2005).

En el caso de los municipios chilenos, la gran limitación de los presupuestos participativos es la escasa disponibilidad de recursos de inversión propia, lo que resta impacto a la participación local. La experiencia en la comuna rural de Illapel indicó un camino incipiente: gran parte de las iniciativas priorizadas por los vecinos -organizados y capacitados por una ONG aliada del municipio- demandaban una inversión de carácter sectorial que depende del ejecutivo y no del municipio. Por ello, en Illapel no se destinaba una partida específica del presupuesto municipal para su deliberación participativa, sino que se acogían las demandas surgidas de la comunidad y se las refería al ámbito de decisión correspondiente. ¿Cómo lograr que el carácter participativo de un proyecto de inversión sea también un criterio de la priorización, que le permita al planificador municipal negociar en mejores términos con las instancias del gobierno central o regional? Esto dependerá tanto de la voluntad política de la administración municipal como de los avances en la incorporación de este tipo de criterios desde arriba, utilizando, por ejemplo, el Instructivo Presidencial de Participación y los compromisos que los sectores han adquirido al respecto (Montecinos 2007).

Si bien el marco legal, cuando existe, es un respaldo significativo, la experiencia indica que no actúa por sí solo. En Colombia, con la misma normativa pro participación los resultados son muy diversos, dependiendo de la voluntad política y de la tradición organizativa previa de la comunidad (Velásquez 2005). La escasa utilización de los mecanismos contemplados en la reforma de 1999 en Chile (audiencia pública, ordenanzas de participación, referéndum comunal) refleja que no basta simplemente con reformar la ley para producir cambios en una cultura política de mayor antigüedad. Algo similar ocurre en Perú, donde se aplican pro forma modalidades de presupuesto participativo, sin que ello signifique necesariamente el fortalecimiento de la participación efectiva (Remy 2005).

Esta realidad conduce a reforzar la hipótesis de que en contextos de insuficiente descentralización, la iniciativa innovadora proviene de centros 
múltiples, vale decir más asociada a programas específicos, muchas veces en alianza con organizaciones de la sociedad civil o con programas públicos también innovadores. En mucha menor medida ella proviene de orientaciones relacionadas al sistema político de gestión municipal, con lo cual se dificulta su difusión e incremento de escala.

Los presupuestos participativos se han extendido a partir de 2005 a un total de 33 municipios chilenos. Entre 2007 y 2009, fueron impulsados por la SUBDERE como parte de la política pro participación del gobierno de Bachelet. La evidencia existente a mediados de 2009 indica que, salvo Negrete, todas las demás experiencias pioneras se encuentran discontinuadas. El programa de la SUBDERE alcanzó una cobertura de 25 municipios, apenas una cuarta parte de su objetivo original y fue discontinuado por el gobierno de Piñera. Aún así surgen nuevas iniciativas en ciudades intermedias como San Antonio, La Serena y Puerto Montt.

Las diferencias de ejecución marcan también las diferencias de potencial de la herramienta adoptada. Mientras algunas comunas han incorporado la metodología a la ordenanza de participación, institucionalizándola, otras han radicado la iniciativa en la voluntad alcaldicia. La estructura municipal actual hace que este mecanismo de participación pueda ser utilizado de manera funcional por el alcalde como una forma de marginar al Concejo Municipal e incluso a la red organizacional comunal (Ochsenius 2005). Más allá de esto, existe la dificultad de implementar esta innovación en un contexto de insuficiente descentralización fiscal y falta de una normativa adecuada.

El interfaz local incluye las iniciativas sectoriales de ejecución local, que normalmente hacen del municipio un actor necesario aunque subordinado, pues el financiamiento y el diseño de los programas permanecen radicados en las agencias sectoriales del nivel central. Este aspecto es clave, ya que la concertación local en comunidades pobres tiene un horizonte muy limitado si no logra renegociar las condiciones extralocales de su desarrollo. Más aún, la continuidad y sostenibilidad de las experiencias participativas depende en gran medida de su capacidad de expandir sus logros e impacto en las condiciones de vida (Bebbington 2005, Panfichi y Dammert 2005). En su estudio sobre un municipio indígena en Ecuador, Anthony Bebbington subraya:

No se puede pensar la concertación sin pensar la pobreza y la economía política al mismo tiempo [...] las posibilidades de concertación están muy influidas por la distribución de activos así como por la productividad de esos activos [...] [Si] falta crecimiento [eso] termina limitando la

8 Egon Montecinos, en comunicación personal. 
posibilidad de que los ciudadanos puedan o quieran participar. Con el tiempo, va restando tanto legitimidad como sostenibilidad a los espacios de concertación pública local que han sido ganados (2005: I 5 ).

Las redes de políticas públicas del nivel municipal, sin embargo, tienden a ser frágiles y volátiles (Cabrero 2004), pues la arquitectura institucional, así como la cultura política de la relación entre administración y sociedad civil en que se insertan, no han experimentado la evolución correspondiente. También en este caso la participación y compromiso ciudadanos resultan defensas determinantes frente a la presión que sufren los municipios desde arriba, en términos de cambios políticos, agendas del gobierno central y otros aspectos. Para que el interfaz funcione debe ser adecuado al contexto en que se desenvuelve y aquí la heterogeneidad es lo que predomina. La estructura política de los Estados y la tradición centralista y homogeneizante dificultan ese proceso (Cabrero 2005: 392), lo que plantea desafíos políticos que pueden favorecer o inhibir este tipo de prácticas y que definen su continuidad en el tiempo.

Es común la afirmación de que es más fácil lograr este tipo de concertación en los contextos locales, pues los actores están más cerca unos de otros y los problemas son menos complejos. Pero el problema de los sistemas locales es su insuficiente autonomía de decisión, su escasa dotación de recursos propios y su inadecuado encadenamiento con las políticas del nivel central y las instancias de decisión nacional. Esta situación demanda una articulación multinivel como requisito de una efectiva concertación local (Blanco y Gomá 2002). La mayor facilidad de establecer la concertación no corre a la par con la efectividad e impacto que pueda lograr.

En la ejecución local de programas sectoriales ha habido algunas iniciativas innovadoras que han logrado establecer una adecuada articulación a partir de algunos rasgos diferenciadores. Por ejemplo, hay iniciativas que plantean metas de desarrollo económico local en comunas pobres, especialmente rurales. Tienen en común haber sido diseñadas específicamente para la pobreza rural, con un enfoque intersectorial, una fuerte articulación de los actores locales y el apoyo de programas, en algunos casos, nacionales. En ellas se combinan metas de generación de ingresos con otras de desarrollo sustentable y preservación del medio ambiente, normalmente impulsadas por organizaciones de la sociedad civil.

Pero las agencias públicas muestran aún grandes limitaciones en relación con estos temas, como se evidenció en un análisis de iniciativas destacadas por el Premio Innovación y Ciudadanía. Este análisis constató que "inexistentes en el sector público son las alusiones a otros enfoques tales como el 'desarrollo sustentable', de derechos ambientales, de 
autodeterminación territorial indígena” (Ochsenius 2004: 26).

\section{LOS INTENTOS DE OUTSOURCING DEL VÍNCULO CON LA SOCIEDAD CIVIL}

Como ya se ha señalado, la arquitectura institucional del Estado chileno fue modificada muy poco a partir de I990, con excepción de la creación de agencias orientadas a actores específicos bajo el alero de MIDEPLAN. Se incrementaron los recursos disponibles y se establecieron nuevos programas, pero no se alteró la estructura de los ministerios y servicios preexistentes. Las excepciones ya las hemos analizado: la creación de los gobiernos regionales como respuesta a una presión de la oposición -no orgánica, sino debida a un cálculo de poder de corto plazo- y la transformación de ODEPLAN en ministerio, con la subsecuente creación de agencias focalizadas de política social en su interior. Con el tiempo, en la medida en que se iban abordando nuevos temas, surgían nuevos servicios o reparticiones. Es el caso de la CONAMA respecto del medio ambiente, el SERNAC para la protección de los consumidores, el SENAMA dedicado a los adultos mayores y el CONACE para el control de drogas y estupefacientes. Transcurrió más de una década para una modificación mayor: la creación en 2003 del Consejo Nacional de la Cultura y las Artes, un equivalente ministerial para un tema disperso en la administración. En 20 i I se aprobó la creación del Ministerio de Desarrollo Social.

Una modalidad preferente de implementación de los programas creados fue la de los fondos concursables y las licitaciones para la externalización de servicios a particulares. Mediante este mecanismo se canalizó gran parte de la actividad gubernamental, que ya no se ejerce directamente como en el pasado. Ahora se realiza a través de la convocatoria al sector privado incluida en algunos casos la sociedad civil organizada- para la ejecución de las tareas previstas por la política pública. En algunos casos la institución misma que se creó fue un fondo para financiar iniciativas, como ocurrió con el FOSIS, el FONADIS, el Fondo de Desarrollo de las Artes y la Cultura (FONDART), reduciendo en algunos ámbitos la totalidad de una política a su modalidad de financiamiento. Algunas de estas instituciones han permanecido así, como fondos, sin dar lugar a una política como tal. Es el caso del FONADIS y el FOSIS. En cambio, el FONDART dio lugar, como se señaló, a la creación del Consejo Nacional de la Cultura y las Artes, que cuenta con el FONDART como uno de sus instrumentos de financiamiento.

El abordaje político de problemas complejos a través de la modalidad de fondos concursables como principal instrumento ha sido determinante para la fragmentación de la sociedad civil organizada. Esto se debe a que los 
fondos incentivan la formación de asociaciones funcionales a la ejecución de los mismos y su actuación en base a proyectos financiables, normalmente de corta duración, montos restringidos y focalización territorial cambiante. En otras áreas de política, como educación y atención a niños en riesgo social, se mantuvo el sistema de subvenciones establecido en los ochenta (Delamaza 2005: 76-79).

De esta manera, la relación que se establece entre Estado y sociedad civil es restringida y unilateral, por más que en algunos casos los proyectos financiados surjan de la propia comunidad. Como señala un experto en planificación del desarrollo, cuya tesis doctoral versó sobre la evaluación del impacto del FOSIS, con aquella forma de relación "centrada en el financiamiento de proyectos, se descuida otras formas de relación mutuamente beneficiosas [...] Una concepción más amplia debiera cubrir funciones de determinación, producción y financiamiento de iniciativas en asociación con las organizaciones sociales" (Salamanca 2002: 273).

No obstante, existen dos iniciativas que han actuado precisamente para corregir esta unilateralidad, creando agencias que representan un avance en cuanto a desarrollar iniciativas conjuntas con la sociedad civil de mayor proyección. Estas agencias no fueron resultado de una planificación deliberada, han tenido destinos y resultados diferentes entre sí y ninguna de las dos ha desplegado las potencialidades que su carácter mixto les hubiera permitido. A través de estas agencias, el Estado intentó externalizar el vínculo con la sociedad civil traspasando recursos a entidades funcionalmente autónomas con financiamiento público, posibilitando intervenciones con un protagonismo más directo de la sociedad civil. Es el caso del Consejo de las Américas y el Consejo para la Superación de la Pobreza (luego convertido en fundación), especialmente a través de su Programa Servicio País. La evidencia empírica muestra las diferencias de las modalidades de actuación de estas dos entidades, sus diferentes destinos en términos de institucionalización y el tipo de vínculo que construyeron entre la política estatal y las organizaciones sociales.

Fondos PÚBLICOS PARA LA CO-ADMINSITRACIÓN DE LA SOCIEDAD CIVIL EN TEMAS AMBIENTALES

El Fondo de las Américas fue creado en 1992, producto de una iniciativa de reducción de deuda bilateral entre Chile y Estados Unidos para el desarrollo de un fondo dedicado a los temas ambientales. Fue parte de una serie de fondos ambientales en América Latina, creados a partir de 1990 en el marco de la Iniciativa para las Américas, impulsada por la administración estadounidense. Esta política permitió condonar parcialmentey/o reorientar los intereses de la deuda pública entre los gobiernos de Estados Unidos y los 
latinoamericanos para financiar la creación de agencias especializadas en la conservación de biodiversidad y la protección y desarrollo socio-ambiental sustentable de zonas degradadas y pauperizadas en la región. Los fondos serían coadministrados por representantes del sector público, la sociedad civil y el gobierno estadounidense.

En Chile, el Consejo de las Américas encargado de administrar el fondo se constituyó en 1993 y comenzó su relación con la sociedad en I995. Este consejo tuvo la particularidad de reunir en su interior a representantes de cuatro ministerios relacionados con el tema ambiental, junto a seis representantes de organizaciones de la sociedad civil, mayoritariamente ONG de desarrollo que participaban en el fondo, electos por ellas mismas. El consejo se completaba con un representante de la Embajada de Estados Unidos. Las ONG eran mayoría en el consejo y entre sus miembros el consejo debía elegir su Presidente. El fondo fue dotado de US\$ I 8.700.000 para desarrollar su trabajo durante ı años, destinándolo íntegramente a organizaciones de la sociedad civil trabajando en el área ambiental. Con el tiempo, el Fondo de las Américas comenzó a administrar otros fondos, de la CONADI y de CONAMA, aprovechando el know-how acumulado. El Fondo financió ocho concursos de proyectos (I995- 2002), 26 proyectos proactivos y seis programas en diversas áreas a partir de 2000. Su inversión se centró en la ejecución de proyectos, en el fortalecimiento de las ONG, en estrategias de colaboración público-privada y en el desarrollo de metodologías innovadoras para abordar problemas ambientales.

El Fondo de las Américas constituyó una modalidad de traspaso de fondos públicos a una entidad coadministrada, con mayoría de la sociedad civil y dedicada íntegramente a trabajar con organizaciones de la sociedad civil (OSC), aliadas a su vez con municipios y otros organismos públicos, complementando de este modo la política gubernamental. El financiamiento del Fondo de las Américas se aprecia claramente entre las iniciativas innovadoras destacadas por el Premio Innovación y Ciudadanía, lo que muestra el impacto positivo del diseño, pues son numerosas las iniciativas destacadas y sostenibles que tuvieron en su momento apoyo del Fondo de las Américas (Programa Ciudadanía y Gestión Local 2000, 200I, 2003, Programa Ciudadanía y Gestión Pública 2005).

El Fondo de las Américas era el único instrumento del que disponía el gobierno para cumplir las funciones mencionadas, por lo que, ante la inminencia del agotamiento de los recursos financieros asignados, sus responsables iniciaron negociaciones para la asignación de un fondo de segunda generación, con el mismo mecanismo inicial. Se obtuvo el apoyo de la Embajada de Estados Unidos, pero no del Ministerio de Hacienda de Chile para una nueva conversión de deuda ni para la asignación de una 
partida presupuestaria del erario nacional. Por lo tanto, el Fondo de las Américas dejó de existir como tal.

Sin embargo, el Consejo de las Américas asumió otros proyectos, como la administración del Fondo Global para la Prevención del VIH/SIDA. Al mismo tiempo, algunos de los representantes de las ONG en el consejo, junto a su Secretario Ejecutivo, conformaron la Fundación Ciudadana para las Américas en 2003, entidad de carácter privado no lucrativo. En 2007 se denunció ante la justicia la mala utilización de los recursos de administración del Fondo Global confiados a la Fundación Ciudadana por parte del Consejo de las Américas, así como otras irregularidades en la gestión del consejo. Aún está en curso un proceso judicial y ninguna de las dos entidades registra actividad.

El Fondo de las Américas, surgido de una iniciativa de cooperación internacional, tuvo un desempeño exitoso durante sus primeros diez años de existencia. Cumplió una función única de apoyo a las OSC en temas ambientales, reflejado en múltiples acciones e instituciones que potenciaron su trabajo con esos recursos. Sin embargo, no logró su institucionalización efectiva, como había ocurrido con el FOSIS y otras instituciones de la primera generación en I990. El Estado chileno no incorporó esta modalidad mixta de coproducción de acciones destinada al fortalecimiento de las OSC, a pesar del apoyo de la cooperación internacional. Los motivos parecen haber sido un criterio de estabilidad macroeconómica que actuó en contra de ingresar más fondos de cooperación al país. Por el monto involucrado y por la existencia de otros proyectos de cooperación no parece ser ese un argumento definitivo.

La experiencia sugiere que el modelo institucional no fue avalado por los responsables políticos y la función de apoyo a las ONG ambientales no fue considerada una prioridad por la administración, prefiriéndose la finalización de la iniciativa. Sin contar con el apoyo público requerido, el fondo evolucionó hacia una forma privatizada y mal regulada, que desembocó en problemas de probidad, mal uso de recursos y, finalmente, un gran desprestigio para los fondos de inversión mixtos entre el Estado y la sociedad civil. Parte de las dificultades de aprobación de la Ley de Asociatividad y Participación Ciudadana en la Gestión Pública en el parlamento se debieron precisamente a la inclusión en dicha ley de un Fondo de Fortalecimiento de la Sociedad Civil, administrado por un consejo mixto con representantes de las OSC. 
COLABORACIÓN PÚBLICO-PRIVADA Y VOLUNTARIOS PARA LA SUPERACIÓN DE LA POBREZA

La segunda iniciativa también transitó desde ser un consejo públicoprivado a una fundación privada no lucrativa, aunque su permanencia ha sido mayor y su actuación diferente. Se trata del Consejo Nacional para la Superación de la Pobreza, luego convertido en fundación. El consejo fue iniciativa del presidente Frei Ruiz-Tagle, en el marco de la prioridad inicial que su gobierno puso en la superación de la pobreza. El gobierno creó un Programa Nacional de Superación de la Pobreza que contó con dos instancias colegiadas. Una fue el Consejo Interministerial Social (CIS), conformado por la totalidad de los ministerios con incidencia en la temática (no sólo los tradicionalmente considerados como ministerios sociales) y presidido por el propio Presidente. La secretaría ejecutiva fue ejercida por MIDEPLAN, quien coordinaba también el Programa Nacional y dentro de él, un Plan Especial de Comunas Pobres.

La segunda instancia fue el Consejo Nacional para la Superación de la Pobreza, compuesto por veinte personas designadas por el Presidente para colaborar-desde la sociedad civil- en la tarea de superación de la pobreza. A diferencia del Consejo de las Américas, no se trataba de consejeros electos sino designados por el Presidente y no provenían de las OSC, sino de diferentes sectores sociales, principalmente del gran empresariado, organismos de voluntariado, iglesias cristianas, dirigentes de ONG y otros profesionales vinculados a temas sociales. Fue presidido inicialmente por el empresario, ex ministro de Vivienda y Urbanismo y hombre de confianza de la Iglesia Católica, Alberto Etchegaray.

En términos de organismo de vocería pública y cooperación públicoprivada en materias de pobreza, el consejo se reunió periódicamente con el CIS hasta mediados de i 996. En ese momento el Programa Nacional de Superación de la Pobreza fue desactivado sin mediar evaluación de sus resultados, renunció el Ministro de MIDEPLAN Luis Maira y dejó de funcionar el CIS. A su vez, el consejo entregó un informellamado La Pobreza: Un Desafío de Equidad e Integración Social. Éste no fue bien recibido por el gobierno y suscitó la oposición de varios de los representantes empresariales, lo que condujo a su marginación del consejo y la desactivación práctica del mismo (Bengoa I999a: I06 - I I I, Raczynski y Serrano 2002). Esto motivó a algunos de los integrantes del consejo a conformar una entidad privada de carácter no lucrativo, la Fundación para la Superación de la Pobreza. Esta entidad ha dado cierta continuidad a la formulación de propuestas para la política social a través de documentos como Una Propuesta para la 


\section{Futura Politica Social (I 999) y otros posteriores9.}

El destino de esta fundación hubiese sido similar a muchas otras si no hubiese sido por un elemento de continuidad desde la constitución del consejo: el financiamiento estatal a través de transferencias del presupuesto estatal. Este financiamiento no se dirigió a la función propositiva y de interlocución con el gobierno descrito previamente. Estas propuestas, como ha ocurrido con la mayoría de este tipo de instancias, han tenido poco impacto en la redefinición de políticas públicas, aún cuando hayan sido convocados por el propio gobierno y mantengan contacto continuo con él. La continuidad del financiamiento estuvo asociada durante todo el período a la ejecución de un programa específico -el Programa Servicio País- y a su expansión a otros programas de voluntariado juvenil.

A través del Programa Servicio País, anualmente un par de cientos de profesionales jóvenes son convocados a trabajar por un período de uno o dos años en comunas rurales pobres, apoyando planes elaborados a demanda de municipios y excepcionalmente gobernaciones, $\mathrm{ONG}$, asociaciones de comunidades indígenas y otros organismos. La labor de los profesionales consiste en organizar a las comunidades, apoyar la estructuración de la demanda local, formular proyectos para su financiamiento y establecer las coordinaciones necesarias entre los organismos públicos y de la sociedad civil para llevarlos adelante. En otros términos, son quienes desarrollan el interfaz local entre comunidad, municipio y servicios públicos, el eslabón ausente de las políticas sociales examinado anteriormente. La convocatoria a los jóvenes profesionales incrementa el interés del programa, por cuanto moviliza un sector especialmente alejado de la participación política.

A partir de 2005, se incorporó un nuevo programa denominado Servicios Comunitarios, con el fin de establecer contratos por seis meses dirigidos principalmente a jóvenes en sectores de pobreza (no indigentes) para realizar servicios a la comunidad, los que son apoyados por ONG y equipos formados por los ex profesionales del Servicio País. La fundación ha desarrollado también otros programas, pero estos no tienen la misma significación y continuidad que ha tenido el Servicio País. En términos financieros, los dos programas mencionados representan más de $90 \%$ del financiamiento que recibe ${ }^{\text {Io }}$.

En 2006, la fundación recibió un presupuesto de alrededor de US\$ 9.000.000 provenientes casi en su totalidad de transferencias del Estado

9 http://www.fundacionpobreza.cl/fnp_secciones.asp?Id_seccion=26. Consultado el Io de septiembre de 2008.

Io http://www.fundacionpobreza.cl/archivos/presupuesto2006.pdf. Consultado el io de septiembre de 2008 . 
(93\% vía MIDEPLAN y Ministerio del Trabajo). A modo de comparación, este financiamiento anual equivale a 50\% de lo que utilizó el Fondo de las Américas en diez años. Otra comparación interesante es con el Fondo para el Fortalecimiento de la Sociedad Civil, dependiente de la División de Organizaciones Sociales del Ministerio Secretaría General de Gobierno. Ese fondo recibió en 2009 casi US\$2.000.000, siendo esta la cifra más alta en su breve historia. Así como ocurría con el Fondo de las Américas, también el Servicio País aparece recurrentemente en la ejecución de iniciativas innovadoras. El Servicio País estuvo en el origen de las iniciativas del Consejo de Desarrollo de las Islas Huichas en Aysén, el Centro para el Desarrollo Sustentable de Caleta Buena en Tocopilla, las acciones de la Asociación Pu Lafkenche en Tirúa, la Asociación de Pequeños Mineros de Cabildo y el programa participativo de la Municipalidad de Alhué, entre muchas otras (Programa Ciudadanía y Gestión Local 2000, 2001, 2003, Programa Ciudadanía y Gestión Pública 2005).

Lo paradojal del caso de la Fundación para la Superación de la Pobreza es que se trata de una figura completamente privada que surgió del fracaso del consejo original, pero que conservó una vinculación privilegiada con el gobierno. Al contrario del Fondo de las Américas, que se ocupaba de fortalecer la sociedad civil, la Fundación para la Superación de la Pobreza moviliza principalmente a la sociedad civil para ir en auxilio del Estado, en particular los municipios rurales, por la vía de un voluntariado profesional, remunerado y temporal.

Los intentos de outsourcing, o externalización del vínculo con la sociedad civil, presentes en las dos iniciativas reseñadas, han permitido desarrollar modelos de intervención en las áreas ambiental y de pobreza mediante los cuales se ha podido vincular grupos organizados de la sociedad civil con la institucionalidad pública y los municipios. Sin embargo, dicha vinculación estuvo asociada en un caso (Fondo de las Américas) con la ejecución de proyectos de duración limitada y no tuvo continuidad institucional por falta de voluntad política gubernamental. En el caso del Programa Servicio País, a pesar de la falta de un marco político orgánico en el Estado, la continuidad y el apoyo han sido mayores y en permanente crecimiento, en un área menos conflictiva y sin comprometer un apoyo directo al fortalecimiento de la sociedad civil. De hecho, en 2005 los programas orientados de manera directa al fortalecimiento de la sociedad civil (Ciudadanía y Gestión Local y Redes Sociales), que no recibían financiamiento público sino de la cooperación internacional, fueron desvinculados de la fundación.

Por tratarse de una fundación privada, no se ha institucionalizado su función en el aparato público. Tampoco ha permitido una mayor 
incidencia en el rediseño de las políticas y programas públicos y una incorporación distinta de la participación ciudadana. La labor desarrollada no ha significado una institucionalización de las instancias de concertación local que surgen desde la acción Servicio País. En 2003, el presidente Lagos nombró a Cecilia Pérez, a la fecha Secretaria Ejecutiva de la Fundación para la Superación de la Pobreza, como Ministra de MIDEPLAN y buscó nombrar en cargos públicos regionales a profesionales provenientes del Servicio País. Sin embargo, ello no se tradujo en una institucionalización de las orientaciones y criterios de acción del programa, pues sólo buscaba inyectar un estilo renovado de acción a la política social del gobierno, que en ese momento atravesaba una aguda crisis.

En ambos casos analizados, la búsqueda de un factor externo que sirva de vínculo con la sociedad civil ha permitido el surgimiento de gran cantidad de iniciativas innovadoras y ha fortalecido la relación entre el Estado y la sociedad en el ámbito local. Sin embargo, no se ha proyectado en una institucionalización de esos vínculos, ni tampoco en reformas del sector público para ampliar su capacidad en estas materias. La tendencia ha consistido en traspasar esas iniciativas a entidades privadas -dejando de lado modelos de gestión mixtos- y sin objetivos claros de fortalecimiento de las contrapartes sociales del sector público.

\section{CONCLUSIONES}

Las principales transformaciones en el vínculo entre el Estado y la sociedad durante los veinte años de gobiernos democráticos posteriores a la dictadura se relacionaron con las políticas públicas, particularmente en el área social, máxima prioridad de la gestión estatal y principal diferencia con la orientación neoliberal previa. Es a partir de esas políticas que se formularon las orientaciones participativas y se buscó asegurar la inclusión social de la democracia recuperada. Por lo tanto, este ángulo es especialmente productivo para la consideración de las potencialidades de construcción democrática en el país. ¿Hasta qué punto modificaciones en las políticas públicas, en un sentido participativo y de fomento de la ciudadanía, pueden contribuir a la construcción de la gobernabilidad democrática?

En este artículo se ha analizado de manera detallada cinco agendas de política social desplegadas desde I990, que han modificado las relaciones entre la rama ejecutiva del Estado y la sociedad civil en diversos ámbitos. Esa diversidad de agendas corrobora la idea de que el Estado no es homogéneo en su comportamiento frente a la sociedad, sino que es objeto de disputa política. Los arreglos institucionales deben comprenderse como resultado y expresión de esa disputa, que va dando un carácter plural al Estado. Sin 
embargo, detectamos también patrones comunes en el comportamiento estatal, que son relevantes para comprender la potencialidad de las políticas públicas para impulsar la democratización. Uno de ellos es la falta de mecanismos institucionalizados de participación ciudadana, aún de los más elementales que pueden desarrollarse en el ámbito local. También se detecta un tipo de vinculación que tiende a la despolitización y a la especialización en torno a programas de provisión de servicios focalizadas en los más pobres. Las reformas más ambiciosas en el ámbito de la ciudadanía (Ley indígena, políticas de género, reforma de la salud, reforma educacional) no han podido ser impulsadas completamente, dadas las limitaciones políticas impuestas por el marco político de la transición. Tampoco han logrado asociar la agenda de fortalecimiento de la ciudadanía pasiva (garantía de derechos) con formas de ciudadanía activa y fortalecimiento de la sociedad civil. Todo ello refuerza un patrón histórico de más larga data: las reformas top down, concebidas homogéneamente para todo el espacio nacional y decididas, por lo tanto, por la elite gobernante sin mayor espacio de expresión de los grupos sociales o comunidades locales específicas.

La diversidad de agendas que vinculan al Estado con la sociedad a través de las políticas públicas releva la importancia y amplitud de este vínculo para la acción estatal. Sin embargo, la investigación indica un desempeño modesto del Estado chileno en cuanto a institucionalizar adecuadamente la participación de las y los ciudadanos, convirtiendo esa participación en un factor de construcción y fortalecimiento democrático. Para ello se revisan varias dimensiones de análisis, en todas las cuales los resultados son extremadamente limitados. Contrasta esta debilidad con otro tipo de resultados de algunas de estas políticas y programas, en relación a una mayor cobertura de servicios, la institucionalización de ciertos derechos sociales y el aumento de infraestructura y servicios sociales, etc. En esos términos, la gestión estatal post-I990 muestra una gran cantidad de logros.

Desde el punto de vista de la actoría social, las agendas surgidas como producto de negociaciones con movimientos organizados -mujeres e indígenas- han evolucionado hacia un divorcio, más que a la continuidad de la cooperación. El movimiento de mujeres se desactivó en la misma medida en que su agenda se institucionalizaba. En tanto, las limitaciones de la Ley Indígena producto de su negociación en el parlamento constriñeron de tal manera sus posibilidades, que fue surgiendo un movimiento indígena autónomo y confrontacional con el gobierno. Influyó también en esta situación la intensificación de la presión que las industrias extractivas de recursos naturales y las grandes obras de infraestructura a su servicio ejercían sobre los territorios y comunidades indígenas.

Los instrumentos contemplados en la negociación inicial y su filtro a través 
de la democracia de los consensos no lograron enfrentar adecuadamente los problemas para los cuales nacieron. En el primer caso, se fortaleció el Estado, pero el rol del movimiento de mujeres fue reemplazado por redes de conocimiento experto, que promovieron una agenda progresiva. En el segundo caso, se fortaleció el movimiento indígena, pero en confrontación con el Estado. Lo que no se fortaleció ni se proyectó en el tiempo fue la co-producción de agendas y bienes públicos, ya sea por el debilitamiento de los actores, o porque el asunto tocaba intereses que estaban fuera de los marcos del consenso inicial de la transición. Se ubica en el campo de lo político más que en el de las políticas públicas, y en ese campo no parecen existir instrumentos disponibles para que los actores aborden y proyecten políticamente estos temas emergentes.

Las formas de participación utilizadas en el resto de las agendas no tienen un carácter institucionalizado y se ejercen más en las etapas de implementación que en la definición de las agendas, como ocurrió en los casos anteriores. Su énfasis está en el espacio micro local (el barrio, la comunidad rural) y se refiere a modalidades de co-financiamiento, de favorecer pequeńas iniciativas de desarrollo local o adecuar parcialmente los instrumentos de inversión pública a pequeña escala. Estas modalidades han dado origen a un importante número de innovaciones locales donde convergen los actores de lo público, generalmente autoridades locales $\mathrm{u}$ operadores de los servicios sectoriales con dirigentes sociales. Muchas de las iniciativas innovadoras analizadas muestran un cierto potencial de fortalecimiento ciudadano -más que capacidad de modificación institucional del Estado-, pero lo hacen a través de unidades específicas y aisladas entre sí. Se multiplican allí donde existen contrapartes sociales organizadas previamente y agentes públicos con voluntad política de apertura, pero sin responder a lineamientos comunes desde el Estado central.

Se puede concluir que el proceso de participación ocupa un espacio institucional reducido y con baja articulación al ciclo de las políticas públicas en las que interviene. Esto debilita su potencial, por cuanto limita sus posibilidades de incremento de escala. En un contexto de políticas focalizadas en sectores pobres y vulnerables, esto tiende a configurar un esquema de participación y concertación de esfuerzos entre pobres (habitantes pobres con municipios pobres, por ejemplo). El potencial de transformación de las condiciones de vida y superación de la pobreza de estos esfuerzos también disminuye. Ello desacopla la agenda de participación de otras políticas como las de superación de la pobreza y protección social, perdiendo la labor social su necesaria alineación.

Los espacios y mecanismos de participación están enraizados (embedded) 
en una trama institucional más amplia. Sus posibilidades de avance, sustentabilidad, apropiación ciudadana, incremento de impacto (scaling up) y capacidad transformadora están en directa relación con la coherencia y articulación interna de los diseños institucionales de la gestión pública. En la medida que el proceso de participación no forma parte estructurante del proceso democrático ni de la toma de decisiones en la gestión estatal, su potencialidad se ve disminuida. La emergencia del neouniversalismo en diversas áreas de la política social introduce una innovación que podría evolucionar hacia modalidades de participación sujetas a estándares y mayor publificación. Las movilizaciones sociales posteriores a la Concertación (20I I) sugieren, sin embargo, que se requerirá de cambios políticos de mayor envergadura que profundicen la democratización para dar cauce a esas posibilidades. 


\section{REFERENCIAS}

Ábalos, J. (1993). La Descentralización en Chile: Antecedentes Históricos y Reformas Actuales. En Instituto de Estudios Urbanos, La Cuestión Regional en la Transición a la Democracia en el Caso de Chile. Santiago: Universidad Católica.

Abramovich, V. (2006). Una Aproximación al Enfoque de Derechos en las Estrategias y Políticas de Desarrollo. Revista de la CEPAL, 88, 35-58.

Aedo, C. (200I). Las Reformas en la Salud en Chile. En Larraín, F. y Vergara, R. (Eds.), La Transformación Económica de Chile. Santiago: Centro de Estudios Públicos.

Aguilera, C. (2009). Un Análisis de las Comisiones Asesoras Presidenciales del Gobierno de Bachelet. Santiago: FLACSO Chile.

Alenda, S. (2004). Evaluación de la Participación Ciudadana en las Experiencias de Desarrollo Integral del Programa Ciudadanía y Gestión Local. Santiago: CEPAL.

Anaya, J. (2009). La Situación de los Pueblos Indigenas en Chile: Seguimiento a las Recomendaciones Hechas por el Relator Especial Anterior. Informe presentado al Consejo de Derechos Humanos de Naciones Unidas, I $2^{\circ}$ período de sesiones. Disponible en http://www.politicaspublicas.net/ panel/reforma/analisis/38 5-reforma-fast.html [17-09-2009].

Angell, A. (1974). Politics and the Labor Movement in Chile. Londres: Oxford University Press.

. (I 999). La Descentralización de Chile. Instituciones y Desarrollo 3, I 3 I-I 72.

Annik, M. (2005). Dos Décadas de Reforma de Salud en Chile: Logros y Desafíos Persistentes. Disponible en http://www.siicsalud.com/dato/ dat043/0562 I024.htm [10-05-2008].

Aravena, S. y Sandoval, A. (2008). Política Habitacional y Actores Urbanos. Seminario del Observatorio Vivienda y Ciudad. Santiago de Chile: Ediciones SUR.

Arenas, G. y Guzmán, J. (2003). Disciplina Fiscal y Protección Social en Chile. Revista de la CEPAL, 8 I, I23-I4I.

Arrau, F. (2002). Conceptualización del Plan de Acceso Universal con 
Garantias Explicitas (AUGE), Eje de la Actual Reforma a la Salud. Santiago: Biblioteca del Congreso Nacional. Disponible en http:// www.bcn.cl/carpeta_temas/temas_portada.2005-I0-27.7644862447/ documentos_pdf.2005-I0-28.232077 I 530/archivos_pdf.2005-I 028.33558 I3890/archivo I/baja_archivo [I O-oI-2009].

Arzola, M. y Castro, R. (2009). Determinantes de la Movilidad de la Pobreza en Chile (1996-2006). En Joignant, A. y Güell, P. (Eds.), El Arte de Clasificar a los Chilenos. Enfoques Sobre los Modelos de Estratificación en Chile. Santiago: Ediciones Universidad Diego Portales.

Avritzer, L. (2002). Democracy and the Public Space in Latin America. Princeton University Press.

Aylwin, J. (2000). Los Conflictos en el Territorio Mapuche: Antecedentes y Perspectivas. Perspectivas, 3 (2), 277-300.

Baldez, L. (1999). La Política Partidista y los Límites del Feminismo de Estado en Chile. En Drake, P. y Jaksić, I. (Eds.), El Modelo Chileno. Democracia y Desarrollo en los Noventa (pp. 407-433). Santiago: LOM Ediciones.

Bebbington, A. (2005). Los Espacios Públicos de Concertación Local y sus Limites en un Municipio Indigena: El Caso de Guamote, Ecuador. Disponible en http://www.innovacionlocal.org/popbiblio.php?id=00000000065 [0305-2009].

Bebbington, A., Delamaza, G. y Villar, R. (2005). El Desarrollo de Base y los Espacios Públicos de Concertación Local en América Latina. Debate Agrario, 40/ 4I, 299-324.

Bengoa, J. (I 999a). Historia de un Conflicto. El Estado y los Mapuches en el Siglo XX. Santiago: Planeta.

. (1999b). Carta Abierta a Eduardo Frei Ruiz-Tagle. Santiago: Planeta.

Blanco, I. y Gomá, R. (Eds.). (2002). Gobiernos Locales y Redes Participativas. Barcelona: Ariel.

Boeninger, E. (1997). La Democracia en Chile. Lecciones de Gobernabilidad. Santiago: Editorial Andrés Bello.

Boisier, S. (2000). Chile: La Vocación Regionalista del Gobierno Militar. EURE, 26 (77), 8 I-I07.

Cabrero, E. (2004). Los Cambios en la Agenda de Políticas Públicas en 
el Ámbito Municipal. Una Visión Introductoria. En Delamaza, G., Fernández, M. y Navarro, I. (Eds.), Innovación y Ciudadanía en la Gestión Territorial. El Rol de los Municipios. Osorno: FGV-CEDERPrograma Ciudadanía y Gestión Local.

. (2005). Acción Pública y Desarrollo Local. México: Fondo de Cultura Económica.

Campero, G. (1998). Organización Sindical y Relaciones Laborales. En Toloza, C. y Lahera, E. (Eds.). Chile en los Noventa. Santiago de Chile: Dolmen/ Presidencia de la República.

Cannobio, L. y Jeri, T. (2007). Estudio: Estado Actual y Requerimientos de la Participación en la Gestión Municipal. Santiago: SUR Profesionales. Disponible en http://comuna.net/pdf/2008/presentaciones/part_ ciudadananov2008.pdf [10-05-2009].

Canto, M. (2006). Políticas Públicas: Participación e Institucionalización. Ponencia presentada al XI Congreso Internacional del CLAD sobre la Reforma del Estado y la Administración Pública. Noviembre, Ciudad de Guatemala. Disponible en http://www.clad.org.ve/fulltext/0055760. pdf [10-08-2008].

Castro, R. y Katz, F. (2004). Movilidad de la Pobreza en Chile. Análisis de la Enuesta Panel I996/200I. Santiago: Instituto Libertad y Desarrollo.

Centro de Estudios de la Mujer (CEM). (1993). Los Contenidos de las Políticas Públicas hacia la Mujer: Las Propuestas de la Concertación de Mujeres por la Democracia y las Acciones del SERNAM. Santiago: Centro de Estudios de la Mujer.

Centro de Derechos Humanos (2008). Informe de Derechos Humanos en Chile. 2007. Santiago: Universidad Diego Portales.

Contesse, J. \& Delamaza, G. (2005). Pobreza y Derechos Humanos en Chile. Análisis de Dos Programas Sociales. Santiago: Universidad de Los Lagos.

Delamaza, G. (I999). Los Movimientos Sociales en la Democratización de Chile. En Drake, P. y Jaksić, I. (Eds.), El Modelo Chileno. Democracia y Desarrollo en los Noventa. Santiago: LOM Ediciones.

. (2005). Tan Lejos tan Cerca. Políticas Públicas y Sociedad Civil en Chile. Santiago: LOM Ediciones.

Delamaza, G y Fernández, M. (2006). Cuando el Viento Sopla desde abajo. Innovaciones Locales Ciudadanas y Gestión Pública. En Varas, 
A. (Ed.), La Propuesta Ciudadana. Relaciones Sociedad Civil-Estado: Argentina, Colombia, Chile y Perú. Santiago: Catalonia.

Delamaza, G. y Ochsenius C. (2007). Innovaciones en los Vínculos entre Sociedad Civil y Estado en Chile: Su Impacto en la Gobernanza Democrática. Ponencia presentada al Congreso de la Latin American Studies Association, octubre, Montreal.

(2008). ¿Participación sin Espacio Público? El Caso de los Presupuestos Participativos en Chile. Ponencia Presentada al Congreso de la Latin American Studies Association, junio, Rio de Janeiro.

Díaz, A. (1998). La Gestión en la Encrucijada: La Política de Participación en las Municipalidades. Proposiciones, 28, 260-274.

Erazo, A. (2004). La Reforma de Salud, una Obligación Social. Foro 2I, septiembre, 8-Io. Disponible en http://www.bcn.cl/carpeta_temas/ temas_portada.2005-I0-27.7644862447/documentos_pdf.2005-I028.232077 I 530/archivos_pdf.2005-I0-28.8265586995/archivo I / baja_archivo [22-09-2007].

Espinoza, V. (2004). De la Política Social a la Participación en un Nuevo Contrato de Ciudadanía. Política, 43, I49-I 84.

Fernández, M. (2006). La Reforma de Salud: Desafíos de Equidad, Ciudadanía Social y Gestión Democrática. En Fernández, M. y Ochsenius, C, Innovaciones, Arreglos Institucionales y Participación Ciudadana: Contribuciones a la Reforma de Salud. Santiago: Programa Ciudadanía y Gestión Pública. Universidad de los Lagos/ Ministerio de Salud.

. (2007). (Ed.). Innovaciones en la Gestión Participativa de la Salud. Lecciones y Aprendizajes 2006. Santiago: Secretaría de Redes Sociales. Unidad de Participación Social.

Fernández, M. y Ochsenius, C. (2006). Innovaciones, Arreglos Institucionales y Participación Ciudadana: Contribuciones a la Reforma de Salud. Santiago: Programa Ciudadanía y Gestión Pública. Universidad de los Lagos/Ministerio de Salud.

Fernández, M. y Ordóñez, M. (2007). Participación Ciudadana en la Agenda Gubernamental de 2007. Caracterización de los Compromisos. Disponible en http://www.innovacionciudadana.cl/portal/imagen/ File/barometro/Informe\%2ofinal\%20S.E..pdf [10-09-2008].

Filgueiras, C. (2005). Los Excluidos y los Procesos de Concertación Pública 
Local. El Caso de Belo Horizonte, Brasil. Disponible en http://www. innovacionlocal.org/biblioteca.php?q=filgueiras\&cr=au\&lang=es [o804-2008].

Foerster, R. y Vergara, I. (2000). Los Mapuches y la Lucha por el Reconocimiento en la Sociedad Chilena. En Castro, M. (Ed.), XII Congreso Internacional de Derecho Consuetudinario y Pluralismo Legal: Los Desafios del Tercer Milenio. Santiago: Universidad de Chile.

Fondo de Solidaridad e Inversión Social (FOSIS). (2002). Documento Puente Final. Santiago: FOSIS.

Foster, B. (2010). Estado de la Investigación en Participación Ciudadana en Chile. Disponible en http://politicaspublicas.ulagos.cl/wp-content/ uploads/ESTADO-INVESTIGACION-PARTICIPACION-B.Foster-20I0.pdf_[02-09-20 Io].

Foxley, A. (2005). Los Objetivos Económicos y Sociales en la Transición a la Democracia. En Pizarro, C. et al. (Eds.), Politicas Económicas y Sociales en el Chile Democrático. Santiago: CIEPLAN/ UNICEF.

Franceschet, S. (2003). 'State Feminism' and Women's Movements: The Impact of Chile's Servicio Nacional de la Mujer on Women's Activism. Latin American Research Review, 38 (I), 9-40.

. (2006). El Triunfo de Bachelet y el Ascenso Político de las Mujeres. Nueva Sociedad, 202, I 3-22.

Garrido, S. (2007). Financiamiento Municipal: Desafio para la Reforma Municipal. Disponible en http://www.subdere.gov.cl/I 5 Io/ article-7 I $978 . \mathrm{html}$ [1 2-05-2009].

Greaves, E. (2003). Municipalities, the Spatial Dispersal of Urban Popular Movements and Institutions of Participatory Governance in Santiago, Chile. Ponencia presentada a la Conferencia de la Latin American Studies Association, marzo, Dallas.

Guerra, C. (1997). Nueva Estrategia Neoliberal: La Participación Ciudadana en Chile. México: UNAM.

Guzmán, V. (2005). La Institucionalidad de Género en el Estado: Una Investigación de las Experiencias de los Mecanismos Estatales de Coordinación de Politicas de Igualdad de Género. Manuscrito. Santiago de Chile.

Hewitt, W. E. (2004). Improving Citizen Participation in Local 
Government in Latin America Through International Cooperation: A Case Study. Development in Practice, I 4 (5), 619-632.

Holzmann R. y Jorgensen, S. (200o). Manejo Social del Riesgo: Un Nuevo Marco Conceptual para la Protección Social y más Allá. Washington: Banco Mundial.

Jones, E. y Gaventa, J. (2002). Concepts of Citizenship. A Review. Brighton: Institute of Development Studies.

Larraín, F. (2008). Cuatro Millones de Pobres. Actualizando la Línea de Pobreza. Estudios Públicos, I09, IоI-I 48.

Lavanchy, J. (1999). Conflictos y Propuestas de Autonomía Mapuche. Disponible en http://www.xs4all.nl/rehue/art/laval.html_[02-092005].

Mallon, F. (1999). Cuando la Amnesia se Impone con Sangre, el Abuso se Hace Costumbre: El Pueblo Mapuche y el Estado Chileno I 88 II 998. En Drake, P. y Jaksić, I. (Eds.), El Modelo Chileno. Democracia y Desarrollo en los Noventa. Santiago: LOM Ediciones.

Mardones, R. (2006). Descentralización y Transición en Chile. Revista de Ciencia Política, 26 (I), 3-24.

Martínez, A. (1996). Los Consejos Escolares en las Escuelas Públicas de Educación Infantil y los Colegios de Educación Primaria. Disponible en http://www.arrakis.es/-antmarti/normas.htm [I 8-09-2009].

Más Voces (2005). Más Democracia. Propuestas para la Participación Ciudadana. Santiago: LOM Ediciones.

Matear, A. (1995). The Servicio Nacional de la Mujer (SERNAM): Women and the Process of Democratic Transition in Chile I990-94. En Hojman, D. (Ed.), Neo-liberalism with a Human Face? The Politics and Economics of the Chilean Model. Liverpool: Institute of Latin American Studies, The University of Liverpool.

Ministerio de Planificación (MIDEPLAN). (2004). Conceptos Fundamentales Sistema de Protección Social. Chile Solidario. Santiago: MIDEPLAN. Santiago de Chile. Autor. Consultado en Mayo io, 2009, desde http://www.mideplan.cl/admin/docdescargas/centrodoc/ centrodoc_I70.pdf [10-05-2009].

. (2005). Programa Orígenes. Disponible en www.origenes.cl [I 5-42005]. 
Ministerio de Educación (MINEDUC). (2005). Manual de Apoyo para Establecer los Consejos Escolares. Santiago: MINEDUC. Disponible en http://6oo.mineduc.cl/docs/resguardo/resg_part/man_conesc.pdf [18-09-2009].

Ministerio de Salud. (20 Io). Estado de Avance de los Objetivos de Impacto. Santiago: Ministerio de Salud.

Molina, S. (I992). El Estado como Superintendente de la Equidad. Cuadernos del Foro 90, I, 7-I 5.

Montecinos, E. (2005a). Los Estudios de Descentralización en América Latina: Una Revisión sobre el Estado Actual de la Temática. EURE, XXXI (93), 73-88.

. (2005b). Antecedentes sobre la Relación Histórica entre Centralismo y Descentralización en Chile. Revista Venezolana de Gerencia, io (3 I). 443-462.

. (2007). Los Límites de la Modernización Municipal para Profundizar la Participación Ciudadana en Chile. ¿Es la Gobernanza de Proximidad una alternativa? Gestión y Política Pública, XVI (2), 319-35 I.

Moulian, T. (1997). Chile Actual. Anatomía de un Mito. Santiago: LOM Ediciones.

. (2006). Fracturas. De Pedro Aguirre Cerda a Salvador Allende (1938I973). Santiago: LOM Ediciones.

Namuncura, D. (1999). Ralco, ¿Represa o Pobreza? Santiago: LOM Ediciones.

Nyamu-Musembi, C. y Cornwall, A. (2004). What is the "Rights-Based Approach" All About? Perspectives from International Development Agencies. Brighton: Institute for Development Studies.

Ochsenius, C. (2004). Sentidos y Redes de Acción Colectiva en los Procesos de Innovación en Ciudadanía. Santiago: Programa Ciudadanía y Gestión Local.

- (2005). Estrategias Focalizadas y Participativas de Superación de la Pobreza y Desarrollo de la Concertación Pública Local: El Caso de Cerro Navia, Chile. Disponible en http://www.innovacionlocal.org/ popbiblio.php?id=00000000068 [22-06-2009].

- (2006). Gestión Pública y Ciudadanía: Participación Social y 
Reforma en el Servicio de Salud Talcahuano 2002-2005. En Fernández, M. (Ed.), Innovaciones en la Gestión Participativa de la Salud. Lecciones $y$ aprendizajes 2006. Santiago: CIC/ MINSAL/ ULA.

Otano, R. (1995). Crónica de la Transición. Santiago: Planeta.

Oxhorn, P. (200 I). La Construcción del Estado por la Sociedad Civil: La Ley de Participación Popular de Bolivia y los Desafios de la Democracia Local. Washington: INDES. Disponible en http://www.lasociedadcivil.org/ docs/ciberteca/ley_boliviai2ocan.pdf [10-7-2008].

Paley, J. (200I). Marketing Democracy. Power and Social Movements in PostDictatorship Chile. Los Angeles: University of California Press.

Palma, J. y Urzúa, R. (2005). Anti-Poverty Policies, Poverty and Citizenry. The "Chile Solidario" Experience. París: MOST/ UNESCO.

Panfichi, A. y Dammert, J. (2005). Participación, Concertación y Confrontación en Espacios Locales. El Caso de la Mesa de Concertación para la Lucha contra la Pobreza del Departamento de Puno. Disponible en http://www.innovacionciudadana.cl/latinoamerica/pdf/Puno\%20 ok.pdf [17-09-2008].

Programa de las Naciones Unidas para el Desarrollo (PNUD). (2000). Más Sociedad para Gobernar el Futuro. Santiago de Chile. PNUD.

Posner, P. (2003). Local Democracy and Popular Participation: Chile and Brazil in Comparative Perspective. Democratization, Io (3), 39-67.

Programa Ciudadanía y Gestión Local. (200o). Los Caminos que Buscamos. 30 Innovaciones para el Fortalecimiento del Espacio Público Local. Santiago: FNSP/ CAPP.

- (200 I). Espacios Locales y Desarrollo de la Ciudadanía. 30 Innovaciones para Construir Democracia. Santiago: CAPP/ FNSP.

- (2003). Ampliando la Ciudadanía, Promoviendo la Participación. Santiago: INAP/ FNSP.

. (2005). Nuevas Experiencias de Gestión Pública Ciudadana. Santiago: Universidad de Los Lagos.

. (2008). Ciudadanía Innovadora en la Región de Coquimbo. Coquimbo: Universidad de Los Lagos/ Gobierno Regional de Coquimbo.

Programa Orígenes. (2008). Re-Conocer. Pacto Socialporla Multiculturalidad. 
Santiago: MIDEPLAN.

Provoste, P. y Valdés, A. (2000). Democratización de la Gestión Municipal y Ciudadanía de las Mujeres: Sistematización de Experiencias Innovadoras. Santiago: Programa Ciudadanía y Gestión Local.

Puentes, G. (2010). Unravelling the Policy-Making Process: The Case of Chilean Poverty-Alleviation Policy. Tesis de doctorado, Department of Social Policy, London School of Economics and Political Science.

Quiero, K. (2005). Los Imaginarios Sociales de la Reforma de la Salud en Chile (1990-2003). Revista MAD, I2, 85-I03

Raczynski, D. et al. (1995). Politicas Económicas y Sociales en el Chile Democrático. Santiago: CIEPLAN.

Raczynski, D. y Serrano, C. (2002). Viejos y Nuevos Problemas en la Lucha contra la Pobreza en Chile. En Muñoz, O. y Stefoni. (Eds.), C, El Periodo del Presidente Frei Ruiz-Tagle. Santiago: FLACSO/ Universitaria.

Remy, M. (2005). Los Múltiples Campos de la Participación Ciudadana en el Perú. Lima: IEP Ediciones.

Ríos, M. (2003). Feminismo Chileno en la Década del Noventa: Paradojas de una Transición Inconclusa. En Panfichi, A. (Ed.), Sociedad Civil, Esfera Pública y Democratización en América Latina: Andes y Cono Sur. México: Fondo de Cultura Económica.

Robles, C. (2009). América Latina y la Protección Social: Avances y Desafíos para su Consolidación. Ponencia presentada en Taller de Expertos: "Protección Social, Pobreza y Enfoque de Derechos: Vínculos y Tensiones", octubre, Santiago.

Rodríguez, A. y Sugranyes, A. (2005). Los con Techo. Un Desafío a la Politica de Vivienda. Santiago: Ediciones SUR.

Rufián, D. (2005). Financiamiento de las Administraciones Locales en Chile. En Casado, G. (Ed.), La Financiación de los Municipios. Experiencias Comparadas. Barcelona: Dickynson.

Ruiz, C. (20 I o). De la República al Mercado. Ideas Educacionales y Politica en Chile. Santiago: LOM Ediciones.

Ruz,M.yPalma,C.(2005).AnálisisdelProcesodeElaboracióneImplementación del Sistema Chile Solidario (Informe Preliminar). Santiago: Instituto de 
Asuntos Públicos, Universidad de Chile. Disponible en http://www. ciudadania.uchile.cl/docs/informechilesolidario.pdf [28-08-2006].

Salamanca, F. (2002). Nuevas Formas de Co-Provisión entre Estado y Sociedad. Proposiciones, 34, 269-278.

Salazar, G. y Pinto, J. (I 999). Historia Contemporánea de Chile I. Estado, Legitimidad, Ciudadanía. Santiago: LOM.

Salman, T. (1998). La Base Social Persistente. Los Nuevos Movimientos Sociales en América Latina: Cambio, Resistencia y Lentitud. Proposiciones, 28, 88-II 7 .

Scherer-Warren, I. (I 999). Cidadania sem Fronteiras: Açôes Coletivas na era da globalização. São Paulo: Hucitec.

Secretaría Metropolitana de Planificación. (2009). ¿Quiénes somos? Historia. Disponible en http://www.serplacrm.cl/quienes/historia.php [I0-092009].

Segovia, O. y Dascal, G. (2000). Espacio Público, Participacióny Ciudadanía. Santiago de Chile: Ediciones SUR.

Sengupta, A. (2006). The Human Rights to Development. En Andreassen, B. y Marks, S. (Eds.), Development as a Human Rights. Legal, Political and Economic Dimensions. Cambridge: Harvard University Press.

Sepúlveda, M. (2009). The Urgent Need to Strengthen Social Protection Systems. Ponencia presentada en UN Conference on the World Financial and Economic Crisis and its Impact on Development, UN General Assembly, junio, Nueva York.

Silva, P. (2004). Doing Politics in a Depoliticised Society. Social Change and Political Deactivation in Chile. Bulletin of Latin American Research, 23 (I), 63-78.

Sintomer, Y. (2005). Los Presupuestos Participativos en Europa: Retos y Desafíos. Reforma y Democracia. Revista del CLAD, 31, 63-92.

Siri, G. (2003). Empleo y Fondos de Inversión Social en América Latina. OIT: Lima. Disponible en http://www.ilo.org/public/spanish/employment/ recon/eiip/download/empfond.pdf [I 2-07-2008].

Sojo, A. (200I). Reformas de Gestión en Salud en América Latina. Revista de la CEPAL, 74, I 39-I 57. 
Subsecretaría de Desarrollo Regional (SUBDERE). (2004). Valoración de los Mecanismos de Participación Ciudadana en el Ámbito Municipal. Santiago: SUBDERE

. (2007). Modelo de Gestión de Calidad de los Servicios Municipales. Disponible en http://www.subdere.gov.cl/I 5 Io/articles-73226_ recurso_2.pdf [18-09-2008].

Taylor, L. (1996). Civilising Civil Society: Distracting Popular Participation from Politics Itself. En Monk, H. y Stanyer, J. (Eds.), Contemporary Political Studies: Proceedings of the Conference of the Political Studies Association. Glasgow: University of Glasgow.

Tedesco, L. (2004). Democracy in Latin America: Issues of Governance in the Southern Cone. Bulletin of Latin American Research, 23 (I), 30-42.

Toledo, V. (200I). Esto También va Haciendo Autonomía. La Estrategia Territorial de las Comunidades Lafkenches de Tirúa. En Programa Ciudadanía y Gestión Local, Espacios Locales y Desarrollo de la Ciudadania. 30 Innovaciones para Construir Democracia. Santiago: FNSP/ CAPP.

. (2005). Panorama de las Políticas Públicas y Derechos Indígenas en Chile: Hechos y Procesos Claves del Año 2004. En Anuario internacional MUNDO INDÍGENA 2005, IWGIA. Copenhagen: IWGIA. Disponible en http://www.wrm.org.uy/paises/Chile/ Anuario_IWGIA_2005.pdf [09-10-2009].

. (2006). Pueblo Mapuche, Derechos Colectivos y Territorio: Desafíos para la Sustentabilidad Democrática. Santiago: LOM Ediciones.

- (2007). Cronología de los Principales Hechos en Relación a la Represión de la Protesta Social Mapuche: Chile 2000-2007. Observatorio Social de América Latina, 22, 277-293.

Valdés, T. (2002). Las Mujeres Protagonistas de los Nuevos Tiempos. En Muñoz, O. y Stefoni. C. (Eds.), El Período del Presidente Frei Ruiz-Tagle (pp. I07-I 54). Santiago: FLACSO/ Universitaria.

Van der Ree, G. (2007). Contesting Modernities. Projects of Modernization in Chile, I964-2006. Amsterdam: Dutch University Press.

Van Klaveren, A. (I998). La Inserción Internacional de Chile. En Toloza, C. y Lahera, E. (Eds.). Chile en los Noventa (pp. I I7-I6o). Santiago: Presidencia de la República/ Dolmen. 
Varas, A. (2006). La (Re)Construcción Democrática del Espacio Público. En Varas, A. (Ed.), La Propuesta Ciudadana. Una Nueva Relación Sociedad Civil-Estado: Argentina, Colombia, Chile y Perú. Santiago: Catalonia.

Velásquez, F. (2005). Los Diseños de Planeación y Participación, las Organizaciones de Base y la Construcción de Espacios Públicos de Concertación Local. Una Mirada a Partir del Caso Colombiano. Disponible en http://www.innovacionciudadana.cl/latinoamerica/ pdf/WP\%20Fabio\%20ok.pdf [1 8-06-2007].

Vergara, M. (2007). Reformas de la Salud en Chile: Avances y Problemas en la Implementación. Santiago: Expansiva. Disponible en http://www. expansivaudp.cl/media/en_foco/documentos/04072007 I I 4 I 4I.pdf [25-02-2009].

Recibido: I9-09-20 I I

Aceptación de la versión final: 04-07-20 2 